\title{
DIVERSIDADE SEXUAL E O CONTEXTO GLOBAL: DESAFIOS A PLENA IMPLEMENTAÇÃO DOS DIRETOS HUMANOS LGBTI
}

\author{
Flávia Piovesan ${ }^{1}$ \\ Sandro Gorski Silva ${ }^{2}$
}

\section{Resumo}

O presente artigo tem como objetivo o estudo dos desafios globais que impedem a plena implementação do direito à diversidade sexual no Brasil. Para tanto, verificou-se a proteção dos direitos dos coletivos sexuais na ordem internacional, por meio da análise dos sistemas global e regionais de proteção dos direitos humanos e da jurisprudência das cortes europeia e interamericana de direitos humanos. No plano interno, o objetivo foi analisar a efetividade do direito fundamental à diversidade sexual, mediante o estudo dos casos emblemáticos julgados nos Tribunais brasileiros. Ao final, elencou-se três fatores que impedem a concretização do direito em estudo:

1. Falta de reconhecimento dos direitos das minorias sexuais como direitos humanos;

2. O processo de globalização econômica, e

3. A emergência dos fundamentalismos religiosos.

Como resultado, aponta-se para uma parcial inclusão dessa população na sociedade, o que reafirma a importância da luta pela plena efetividade desses direitos, a fim de que a todo indivíduo seja garantida a livre expressão da sua sexualidade.

Palavras-chave: 1. Direitos Humanos. 2. Diversidade Sexual. 3. Luta pela Dignidade. 4. Efetividade. 5. Contexto Global.

\section{INTRODUÇÃO}

Nos últimos anos, as pessoas Lésbicas, Gays, Bissexuais e Transexuais (LGBTI) ${ }^{3}$ têm enfrentado inúmeros desafios para ver implementado o direito à diversidade sexual nas sociedades contemporâneas. Um

\footnotetext{
${ }^{1}$ Professora doutora em Direito Constitucional e Direitos Humanos da Pontifícia Universidade Católica de São Paulo, Professora de Direitos Humanos dos Programas de Pós Graduação da Pontifícia Universidade Católica de São Paulo, da Pontifícia Universidade Católica do Paraná e da Universidade Pablo de Olavide (Sevilha, Espanha).E-mail: flaviapiovesan@terra.com.br

2 Mestrando em Direito Socioambiental e Sustentabilidade da Pontifícia Universidade Católica do Paraná. E-mail: sandrogorski@gmail.com

${ }^{3}$ Essa é a sigla mais comumente utilizada para designar essa população, notadamente por ser mais completa e abrangente, incorporando a figura dos intersexuais. No entanto, é bastante comum a utilização em documentos, tanto nacionais quanto internacionais, tão somente da sigla LGBT. Vale dizer que a sigla GLS (Gays, Lésbicas e Simpatizantes) não é adotada pelos vol. 08, nº. 04, Número Especial. Rio de Janeiro, 2015.pp. 2613-2650 2613
} 
importante componente dessa luta atém-se ao reconhecimento dos direitos LGBTI tanto na ordem jurídica nacional quanto internacional.

Partindo da concepção de que os direitos humanos refletem uma racionalidade de resistência, traduzindo processos que abrem e consolidam espaços de luta pela dignidade humana, tal qual os concebe Joaquín Herrera Flores, o presente trabalho pretende avaliar quais são os desafios para a plena implementação do direito à livre manifestação da orientação sexual e da identidade de gênero no Brasil.

Nessa perspectiva, analisou-se o processo de luta pela emancipação da população LGBTI no Brasil, seguido do estudo dos casos emblemáticos submetidos às cortes regionais de direitos humanos, em especial, a europeia e a interamericana.

No plano interno, buscou-se verificar qual é o estado do Brasil em relação à proteção do direito à diversidade sexual, qual é a extensão dos efeitos da decisão da Suprema Corte brasileira na ordem jurídica a e quais são os obstáculos que a população LGBTI enfrenta na luta por uma vida digna.

Por último, sustentou-se que a efetivação do direito à diversidade sexual depende do enfrentamento da falta de afirmação dos direitos LGBTI como direitos humanos, da superação dos efeitos negativos do processo de globalização econômica, que transportou para o Brasil uma estrutura incompatível com a proteção daqueles direitos, e da superação dos fundamentalismos religiosos que estão impedindo o avanço legislativo nessa temática.

Ambiciona-se, portanto, reafirmar a importância do processo de luta pelo reconhecimento dos direitos humanos LGBTI na consolidação de uma sociedade mais justa e igualitária, sem discriminação de qualquer espécie.

\section{OS DIREITOS HUMANOS E A DIVERSIDADE SEXUAL}

\section{Os direitos humanos como processos de luta pela dignidade ${ }^{4}$}

Os direitos humanos refletem uma conquista axiológica da pessoa humana, imprimindo ao indivíduo a qualidade de fundamento último da ordem jurídica. Traduzem, sob os primados da Justiça e do Direito,

movimentos sociais, uma vez que não reflete as reivindicações políticas da comunidade. Ao revés, o termo GLS refere-se ao segmento do mercado consumidor conhecido como Pink Market e, portanto, é utilizado para definir os produtos, serviços, espaços e eventos direcionados para esse público. Sobre esse tipo de mercado ver SILVA, Sandro Gorski. A segmentação do consumo e o Pink Market: uma análise do mercado LGBT. Revista de Direito Empresarial, Belo Horizonte, ano 12, n. 1, p. 179-193, jan./abr. 2015.

${ }^{4}$ Este tópico tem como base o artigo Proibição da Discriminação por Orientação Sexual nos Sistemas Regionais Europeu e Interamericano de Proteção dos Direitos Humanos in PIOVESAN, Flávia. Temas de Direitos Humanos. 7a ed. São Paulo: Saraiva, 2014, p. 429-447. 
mecanismos protetivos que, numa perspectiva ex parte populi, foram colocados à disposição do indivíduo contra toda forma de dominação, exclusão e opressão perpetradas ao longo da história.

No dizer de Joaquin Herrera Flores (mimeo, p.7), os direitos humanos compõem uma racionalidade de resistência, na medida em que traduzem processos que abrem e consolidam espaços de luta pela dignidade humana. Invocam uma plataforma emancipatória voltada à proteção da dignidade humana e à prevenção do sofrimento. $\mathrm{O}$ victim centric approach $^{5}$ é a fonte de inspiração que move a arquitetura protetiva internacional dos direitos humanos - toda ela destinada a conferir a melhor e mais eficaz proteção às vítimas reais e potenciais de violação de direitos.

Em diversas civilizações, as mais graves violações aos direitos humanos tiveram como fundamento a dicotomia do "eu versus o outro", a partir da qual a diversidade era captada como elemento para aniquilar direitos. A diferença era visibilizada para conceber o "outro" como um ser menor em dignidade e direitos, ou, em situações limites, um ser esvaziado mesmo de qualquer dignidade, um ser descartável, um ser supérfluo, objeto de compra e venda (como na escravidão) ou de campos de extermínio (como no nazismo). No mundo contemporâneo, as violações com base no racismo, no sexismo, na xenofobia, na homofobia, na lesbofobia, na bisfobia, na transfobia, dentre outras práticas de intolerância, continuam persistindo na tentativa de deixar o ser humano sem lugar no mundo comum.

O temor à diferença é o fator que permite compreender a primeira fase de proteção dos direitos humanos, marcada pela tônica da proteção geral e abstrata, com base na igualdade formal - eis que o legado do nazismo pautou-se na diferença como base para as políticas de extermínio, sob o lema da prevalência e da superioridade da raça pura ariana e da eliminação de todas as demais.

Torna-se, contudo, insuficiente tratar o indivíduo de forma genérica, geral e abstrata. Faz-se necessária a especificação do sujeito de direito, que passa a ser visto em sua peculiaridade e particularidade. Nesta ótica, determinados sujeitos de direitos, ou determinadas violações de direitos, exigem uma resposta específica e diferenciada. Neste cenário as mulheres, as crianças, as populações afro-descendentes, os povos indígenas, os migrantes, as pessoas com deficiência, a população LGBTI, dentre outras categorias vulneráveis, devem ser visibilizadas nas especificidades e peculiaridades de sua condição social. Ao lado do direito à igualdade, surge, também como direito fundamental, o direito à diferença. Importa o respeito à diferença e à diversidade, o que lhes assegura um tratamento especial.

\footnotetext{
${ }^{5}$ A "abordagem centrada na vítima" (tradução livre) é a racionalidade que fundamenta os mecanismos de proteção dos direitos humanos. Esse pensar reflete práticas que objetivam fornecer uma resposta às vítimas que tiveram seus direitos humanos violados, compensando os danos causados e responsabilizando os violadores.
} 
Destacam-se, assim, três vertentes no que tange à concepção da igualdade:

1. A igualdade formal, reduzida à fórmula "todos são iguais perante a lei" (que, ao seu tempo, foi crucial para a abolição de privilégios);

2. A igualdade material, correspondente ao ideal de justiça social e distributiva (igualdade orientada pelo critério socioeconômico); e

3. A igualdade material, correspondente ao ideal de justiça como reconhecimento de identidades (igualdade orientada pelos critérios de gênero, orientação sexual, idade, raça, etnia e demais critérios).

Para Nancy Fraser $(1997)^{6}$, a justiça exige, simultaneamente, redistribuição e reconhecimento de identidades. O direito à redistribuição requer medidas de enfrentamento da injustiça econômica, da marginalização e da desigualdade econômica, por meio da transformação nas estruturas socioeconômicas e da adoção de uma política de redistribuição. De igual modo, o direito ao reconhecimento requer medidas de enfrentamento da injustiça cultural, dos preconceitos e dos padrões discriminatórios, por meio da transformação cultural e da adoção de uma política de reconhecimento. É à luz dessa política de reconhecimento que se pretende avançar na reavaliação positiva de identidades discriminadas, negadas e desrespeitadas; na desconstrução de estereótipos e preconceitos; na valorização da diversidade cultural.

Se, para a concepção formal de igualdade, esta é tomada como pressuposto, como um dado e um ponto de partida abstrato, para a concepção material de igualdade, esta é tomada como um resultado ao qual se pretende chegar, tendo como ponto de partida a visibilidade às diferenças. A ótica material objetiva construir e afirmar a igualdade com respeito à diversidade.

Nesse processo, a Declaração Universal dos Direitos Humanos de 1948 inova a gramática dos direitos humanos, ao introduzir a chamada concepção contemporânea de direitos humanos, marcada pela universalidade e indivisibilidade desses direitos. Universalidade porque clama pela extensão universal dos direitos humanos, sob a crença de que a condição de pessoa é o requisito único para a titularidade de direitos, considerando o ser humano como um ser essencialmente moral, dotado de unicidade existencial e dignidade, esta como valor intrínseco à condição humana. Indivisibilidade porque a garantia dos direitos civis e políticos é condição para a observância dos direitos sociais, econômicos e culturais e vice-versa.

\footnotetext{
6 A respeito ver também: Axel Honneth, The Struggle for Recognition: The moral grammar of social conflicts, Cambridge/Massachussets, MIT Press, 1996; Nancy Fraser e Axel Honneth, Redistribution or Recognition? A politicalphilosophical exchange, London/NY, verso, 2003; Charles Taylor, The politics of recognition in: Charles Taylor et. al., Multiculturalism - Examining the politics of recognition, Princeton, Princeton University Press, 1994; Iris Young, Justice and the politics of difference, Princenton, Princenton University Press, 1990; e Amy Gutmann, Multiculturalism: examining the politics of recognition, Princenton, Princenton University Press, 1994.
} 
A Declaração inaugurou no cenário mundial uma política de reconstrução da proteção da dignidade humana, que, posteriormente, em meio a inúmeros tratados e convenções internacionais, consolidou um sistema normativo internacional de proteção dos direitos humanos e, igualmente, motivou o surgimento de similares sistemas no âmbito regional, o que rompeu, em definitivo, com o conceito de soberania absoluta vigente até então, permitindo, em última análise, a responsabilização dos Estados pelos atos de barbárie.

Nessa ótica, os diversos sistemas de proteção de direitos humanos interagem em benefício dos indivíduos protegidos. Ao adotar o valor da primazia da pessoa humana, estes sistemas se complementam, somando-se ao sistema nacional de proteção, a fim de proporcionar a maior efetividade possível na tutela e promoção de direitos fundamentais. Esta é inclusive a lógica e principiologia próprias do Direito Internacional dos Direitos Humanos.

Todavia, antes de adentrar na análise propriamente dita dos instrumentos protetivos dos direitos da população LGBTI, faz-se necessário analisar o processo de resistência e luta enfrentado pelas minorias sexuais na persecução de uma vida digna.

\section{A luta pela dignidade da população lgbti}

As relações entre pessoas do mesmo sexo são notadas desde as civilizações ancestrais, revelando que esse comportamento faz parte da história da humanidade. Na Grécia Antiga, por exemplo, Alexandre, o Grande, e Zenão de Cítio, fundador do estoicismo, eram conhecidos pelo exclusivo interesse em meninos e outros homens (PICKETT, 2015). A história conta também que a sodomia não era só idiossincrasia grega, mas também estava presente em múltiplas culturas, que a ritualizavam e aceitavam-na socialmente, inclusive, como etapa do processo educacional. Há, ainda, povos que sempre consideraram a figura do travesti e/ou do transexual uma espécie superior ou até mesmo divina.

No mundo ocidental, a ruptura desse paradigma ocorre com o advento do cristianismo, que passa a castigar as práticas sexuais entre pessoas do mesmo sexo por atentar as leis divinas. Inicia-se, assim, todo um processo de perseguição da Igreja contra as minorias sexuais, tendo essa repressão atingido o seu ápice no período da Santa Inquisição. Nessa época, diante da unidade entre Estado e Igreja, as discussões religiosas influenciavam sobremaneira o discurso jurídico, o que levou o III Concílio de Latrão, em 1179, a classificar o crime de pederastia. Posteriormente, a primeira codificação ocidental atribuiu pena de morte aos homossexuais (DIAS, 2009, p. 38).

Foi somente a partir da ruptura com a Igreja, quando o casamento passa a ser oficializado pelo Estado, sem, contudo, deixar de lado seu caráter patrimonial, que emergem novas estruturas de convívio, o que deu início 
à construção do cenário que tornou possível, no final do século XX, o reconhecimento de outras formas de afeto, consagrando a ideia de que a relação entre pessoas de igual sexo é fruto da expressão da sexualidade humana, impossível de ser criminalizada (DIAS, 2009, p. 41).

No campo científico, quem primeiramente se dedicou ao estudo do tema foi o austríaco Karoly Maria Benkert, a quem se atribui a criação do termo "homossexual". Ele concluiu, em 1869, que a homossexualidade era uma condição humana e, não, mera preferência. Mais tarde, surgiram grupos de médicos que a chamaram de perversão sexual, por se afastar da heterossexualidade (GIRARDI, 2005, p. 67).

Nesse período, a medicina, utilizando-se do aparato científico disponível no século XIX, definiu o comportamento homossexual como sendo uma atração sexual e afetiva, caracterizada por um desvio comportamental (GIRARDI, 2005, p. 66), o que justificou o acréscimo do sufixo "ismo" ao termo homossexual, a fim de tornar expressa a referência a um distúrbio mental, a uma moléstia.

Esse paradigma só foi rompido no final da década de 40 do século XX, com a emergência de uma revolução sexual fundamentada nos experimentos empíricos realizados nos Estados Unidos por Alfred Kinsey que sinalizavam que a homossexualidade não era doença e, portanto, deveria ser compreendida como uma variação da sexualidade humana.

Ao lado da proposição de Kinsey, grupos formados por pessoas LGBTI iniciaram paulatinamente um processo de luta por dignidade e igualdade de tratamento contra o Estado que, constantemente, violava seus direitos e não lhes dedicava qualquer reconhecimento jurídico. Com efeito, algumas organizações preocupadas com o bem-estar dessa comunidade começaram a surgir mundo afora. Nos Estados Unidos, a Mattachine Society, fundada em 1951 em Los Angeles, dedicava-se ao combate do uso da lei penal para prender homens gays e fechar bares temáticos. A Daughters of Bilitis, criada em 1955, em São Francisco, buscava criar uma alternativa social aos bares lésbicos. Em 1961, uma célula da Mattachine se fixou em Washington e, dois anos mais tarde, aliou-se, no âmbito local, a American Civil Liberties Union (Sindicato Americano das Liberdades Individuais), a fim de persuadir a esfera nacional da entidade a adotar medidas para descriminalização de práticas sexuais consensuais entre adultos do mesmo sexo (POLIKOFF, 2008, p. 36).

De toda sorte, o ponto de inflexão dos direitos gays no ocidente ocorreu alguns anos mais tarde, entre os dias 27 e 29 de junho de 1969, no bar Stonewall Inn, situado no Greenwich Village, cidade de Nova Iorque, e ficou conhecido como o "Motim de Stonewall”, em razão do confronto desencadeado pelo Estado ao empregar o uso

\footnotetext{
${ }^{7}$ Alfred Kinsey ficou conhecido como o pai da sexologia, ao elaborar um relatório sobre a sexualidade humana nos Estados Unidos no final da década de 40. As conclusões do relatório são objeto de severas críticas por Judith Reisman, na obra Kinsey: Crimes \& Consequences, The Red Queen \& The Grand Scheme. 4a ed. Institute for Media Education, 2012.
} 
da força na tentativa de dissuadir os manifestantes (POLIKOFF, 2008, p. 35). Essas manifestações levaram à criação da Gay Liberation Front (Frente da Libertação Gay), que, por sua vez, instalou grupos pela libertação gay em várias cidades dos Estados Unidos, fortalecendo a ideia de um novo movimento, com propostas diferentes das anteriores, tanto na retórica revolucionária quanto na vontade de questionar a conformidade de gênero. A partir de então, as pessoas LGBTI passaram a viver com orgulho e assumidamente a sua identidade sexual (POLIKOFF, 2008, p. 36).

Desse modo, o discurso LGBTI passou a ir ao encontro das demandas de outros grupos sociais como, por exemplo, heterossexuais divorciados, pessoas que viviam juntas sem se casar, filhos nascidos fora do casamento e feministas. Com efeito, em 1970, inspirados pelo ocorrido em Nova Iorque, gays e feministas juntaram-se para paralisar a convenção nacional da Associação Americana de Psiquiatria, em São Francisco, nos Estados Unidos. A interrupção aconteceu no momento em que se apresentou um documento que estipulava tratamento para mudança da orientação sexual, utilizando-se de choque elétrico e drogas, em conjunto com imagens sexualmente provocantes com pessoas do mesmo sexo (POLIKOFF, 2008, p. 37).

Esses protestos foram responsáveis por desmistificar o estereótipo negativo da homossexualidade, razão pela qual, finalmente, em 1974, aquela associação retirou-a da condição de distúrbios mentais (DIAS, 2009, p. 53). Em 1993, a Organização Mundial da Saúde (OMS) removeu a concepção da homossexualidade do capítulo de "Desvios e Transtornos Sexuais" do Código Internacional de Doenças (CID), passando-a para o capítulo de "Sintomas Decorrentes de Circunstâncias Psicossociais". A eliminação definitiva do comportamento homossexual do código de doenças só aconteceu, no entanto, em 1995 (DIAS, 2009, p. 53).

No Brasil, embora de um lado a prática da homossexualidade nunca tenha sido criminalizada, exceto no período colonial e no âmbito das forças armadas, de outro, quaisquer direitos foram reconhecidos às minorias sexuais pelo ordenamento jurídico, confirmando a vigência de um paradigma de negação, de exclusão dos coletivos sexuais ao longo de grande parte da nossa história. Por aqui, os movimentos sociais começam a surgir somente com o fortalecimento da oposição ao governo militar no final da década de 70 como, por exemplo, o Grupo Gay da Bahia, fundado pelo ativista Luiz Mott, que reclama o título de mais antiga associação brasileira de defesa dos direitos humanos dos homossexuais. Após a queda do governo militar, os movimentos sociais organizados intensificam a mobilização para promover a dignidade das pessoas LGBTI e tentar incluir a proibição da discriminação por orientação sexual no texto da nova Constituição da República Federativa do Brasil. Sem êxito, a questão seguiu sem ser abordada pelo sistema jurídico brasileiro até 2006, ano em que foi promulgada a 
Lei Maria da Penha, a qual considera a orientação sexual para fins de construção familiar ${ }^{8}$, rompendo parcialmente com a falta legislativa sobre $\mathrm{o}$ assunto.

Em relação aos transexuais, verifica-se que o processo de invisibilidade social ainda está bastante presente na sociedade contemporânea, na medida que essa modalidade de identidade sexual ainda é catalogada como doença pela OMS e pela Associação de Psiquiatria Americana9. O comportamento vem descrito no CID como sendo um "Transtorno de Identidade de Gênero", fato que tem motivado movimentos sociais mundo afora a realizarem uma campanha para que na próxima revisão do código haja a despatologização da vivência de identidade de gênero, intensão essa que conta com a participação de diversas entidades no Brasil ${ }^{10}$.

A tipificação patológica desses comportamentos parece ter tido certa relevância em determinado período histórico, garantindo uma suposta proteção contra a tirania estatal e religiosa, dado o fato de que esses entes vislumbravam as manifestações da sexualidade fora do padrão heterossexual como pecado ou, ainda, como crime. No entanto, esse discurso médico tem legitimado, na atualidade, a exclusão social, a violação de direitos e o comportamento discriminatório, que tanto contribui para marginalização de pessoas LGBTI.

Nesse aspecto, testemunha-se também a emergência de grupos religiosos que, nos últimos anos, têm ganhado força no Poder Legislativo brasileiro, construindo uma bancada fundamentalista, cujo objetivo é a tentativa de impor a moral, os "bons costumes" e a liberdade religiosa acima da gramática dos direitos humanos. Vislumbra-se que essa é mais uma tentativa de captar a diferença como elemento para aniquilar direitos, para discriminar, a exemplo do que se verificou ao longo da história.

Vale dizer, a discriminação significa toda distinção, exclusão, restrição ou preferência que tenha por objeto ou resultado prejudicar ou anular o exercício, em igualdade de condições, dos direitos humanos e liberdades fundamentais, nos campos político, econômico, social, cultural, civil ou em qualquer outro âmbito. Logo, a discriminação significa sempre desigualdade.

\footnotetext{
${ }^{8} \mathrm{O}$ art. $2^{\circ}$ da Lei no $11.340 / 2006$ estabelece expressamente que estão atendidas pela lei todas as mulheres, independentemente da orientação sexual, estendo, portanto, a proteção jurídica às famílias homoafetivas. Disponível em: <http://www.planalto.gov.br/ccivil_03/_ato2004-2006/2006/lei/111340.htm>.

${ }^{9}$ A classificação feita pela OMS ( $\left.\overline{C I D}\right)$ orienta a saúde no mundo, por isso muitas entidades a seguem. O Conselho Federal de Medicina brasileiro, por exemplo, adota a definição da organização e segue considerando a transexualidade como doença. Ver Resolução CFM no 1.955/2010, disponível em: <http://www.portalmedico.org.br/resolucoes/CFM/2010/1955_2010.htm>. Quanto à Associação Brasileira de Psiquiatria (ABP) somente se tem notícia do posicionamento da entidade em relação à homossexualidade. Após a desclassificação pela OMS, a ABP não mais a vinculou à doença. A respeito ver "Mais um ponto final na luta dos homossexuais”, disponível em http://oglobo.globo.com/sociedade/saude/mais-um-ponto-final-na-luta-doshomossexuais-7059597.

${ }^{10}$ Nesse sentido ver a campanha internacional Stop Trans Pathologization, disponível no site: <http://www.stp2012.info/old/pt>. vol. 08, nº. 04, Número Especial. Rio de Janeiro, 2015.pp. 2613-2650 2620
} 
Com efeito, verificar-se-á, em seguida, qual é a confluência entre o grau de proteção da cláusula da igualdade e não discriminação e o direito à diversidade sexual nos sistemas global e regionais europeu e interamericano; bem como qual tem sido o impacto da jurisprudência fomentada pelas Cortes Europeia e Interamericana na proibição da discriminação por orientação sexual.

\section{A PROTEÇÃO DOS DIREITOS DA POPULAÇÃO LGBTI NA ORDEM JURÍDICA INTERNACIONAL ${ }^{11}$}

Sob o prisma do sistema global de proteção, constata-se que o direito à vida, à liberdade, à igualdade e à proibição da discriminação foram enfaticamente consagrados pela Declaração Universal de 1948, pelo Pacto Internacional dos Direitos Civis e Políticos e pelo Pacto Internacional dos Direitos Econômicos, Sociais e Culturais, ambos de 1966.

A Declaração Universal de 1948, em seu artigo 1º, desde logo enuncia que "todas as pessoas nascem livres e iguais em dignidade e direitos". Prossegue, no artigo $2^{\circ}$, a endossar que "toda pessoa tem capacidade para gozar os direitos e as liberdades estabelecidos na Declaração, sem distinção de qualquer espécie, seja de raça, cor, sexo, língua, religião, opinião política ou de outra natureza, origem nacional ou social, riqueza, nascimento, ou qualquer outra condição". Dispõe o artigo $3^{\circ}$ que "todo indivíduo tem direito à vida, à liberdade e à segurança pessoal". Estabelece o artigo 7o, por sua vez, a concepção da igualdade formal, prescrevendo que "todos são iguais perante a lei e têm direito, sem qualquer distinção, a igual proteção da lei".

Portanto, se o primeiro artigo da Declaração afirma o direito à igualdade, o segundo artigo adiciona a cláusula da proibição da discriminação de qualquer espécie, como consequência do princípio da igualdade. $\mathrm{O}$ binômio da igualdade e da não discriminação, afirmado pela Declaração, sob a inspiração da concepção formal de igualdade, impactará a feição de todo sistema normativo global de proteção dos direitos humanos.

O Pacto Internacional dos Direitos Civis e Políticos de 1966, já em seu artigo 2 (1), consagra que:

Os Estados Partes do presente pacto comprometem-se a respeitar e garantir a todos os indivíduos que se achem em seu território e que estejam sujeitos a sua jurisdição os direitos reconhecidos no presente Pacto, sem discriminação alguma por motivo de raça, cor, sexo, língua, religião, opinião política ou de outra natureza, origem nacional ou social, situação econômica, nascimento ou qualquer condição.

Uma vez mais, afirma-se a cláusula da proibição da discriminação para o exercício dos direitos humanos.

\footnotetext{
${ }^{11}$ Este tópico tem como base o artigo Proibição da Discriminação por Orientação Sexual nos Sistemas Regionais Europeu e Interamericano de Proteção dos Direitos Humanos in PIOVESAN, Flávia. Temas de Direitos Humanos. 7a ed. São Paulo: Saraiva, 2014, p. 429-447.
} 
A relevância de tal cláusula é acentuada pelo artigo 4º do Pacto, ao prever um núcleo inderrogável de direitos, a ser preservado ainda que em situações excepcionais e ameaçadoras, admitindo-se, contudo, a adoção de medidas restritivas de direitos estritamente necessárias, "desde que tais medidas não acarretem discriminação alguma apenas por motivo de raça, cor, sexo, língua, religião ou origem social”.

A concepção da igualdade formal, tal como na Declaração, é prevista pelo Pacto, em seu artigo 26, ao determinar que:

Todas as pessoas são iguais perante a lei e têm direito, sem discriminação alguma, a igual proteção da Lei. [...] a lei deverá proibir qualquer forma de discriminação e garantir a todas as pessoas proteção igual e eficaz contra qualquer discriminação por motivo de raça, cor, sexo, língua, religião, opinião política ou de outra natureza, origem nacional ou social, situação econômica, nascimento ou qualquer outra situação.

O Comitê de Direitos Humanos, em sua Recomendação Geral nº18, a respeito do artigo 26, entende que o princípio da não discriminação é um princípio fundamental previsto no próprio Pacto, condição e pressuposto para o pleno exercício dos direitos humanos nele enunciados. No entender do Comitê: "Nondiscrimination, together with equality before the law and equal protection of the law without any discrimination, constitute a basic and general principle relating to the protection of human rights" ${ }^{\prime 2}$.

Ressalte-se que, em 1994, no caso Toonen vs. Australia, o Comitê de Direitos Humanos sustentou que os Estados estão obrigados a proteger os indivíduos da discriminação baseada em orientação sexual.

Por sua vez, o Pacto Internacional dos Direitos Econômicos, Sociais e Culturais de 1966, em seu artigo II, estabelece que os Estados-partes comprometem-se a garantir que os direitos nele previstos serão exercidos sem discriminação alguma por motivo de raça, cor, sexo, língua, religião, opinião política ou de qualquer outra natureza, origem nacional ou social, situação econômica, nascimento ou qualquer outra situação. Uma vez mais, consagrase a cláusula da proibição da discriminação. Em sua Recomendação Geral no 20, o Comitê dos Direitos Econômicos, Sociais e Culturais observou que a expressão "outra situação" constante do artigo $2^{\circ}$ do Pacto inclui a orientação sexual. Realçou o dever dos Estados-partes de assegurar que a orientação sexual de uma pessoa não signifique um obstáculo para a realização dos direitos enunciados no Pacto, como, por exemplo, direitos

\footnotetext{
12 "A não discriminação, assim como a igualdade perante a lei e a igual proteção da lei sem nenhuma discriminação, constituem um princípio básico e geral, relacionado à proteção dos direitos humanos” (Tradução livre). Disponível em: <http://tbinternet.ohchr.org/_layouts/treatybodyexternal/Download.aspx?symbolno=INT\%2fCCPR\%2fGEC\%2f6622\&Lang =en>. No mesmo sentido, destaca-se a Recomendação Geral n.14 do Comitê sobre a Eliminação de todas as formas de Discriminação Racial, adotada em $1993 . \quad$ Disponível http://tbinternet.ohchr.org/_layouts/treatybodyexternal/Download.aspx?symbolno=INT\%2fCERD\%2fGEC\%2f7486\&Lang= en.
} 
previdenciários, adicionando que a cláusula da proibição da discriminação alcança o critério da identidade de gênero.

O Comitê dos Direitos Econômicos, Sociais e Culturais, em sua Recomendação Geral no 16, adotada em 2005, afirma ainda que "guarantees of non-discrimination and equality in international human rights treaties mandate both de facto and de jure equality. De jure (or formal) equality and de facto (or substantive) equality are different but interconnected concepts"13.

A Declaração Universal e os Pactos invocam, assim, a primeira fase de proteção dos direitos humanos, caracterizada pela tônica da proteção geral, genérica e abstrata, sob o lema da igualdade formal e da proibição da discriminação.

A segunda fase de proteção, reflexo do processo de especificação do sujeito de direito, será marcada pela proteção específica e especial, a partir de tratados que objetivam eliminar todas as formas de discriminação que afetam de forma desproporcional determinados grupos, como as minorias étnico-raciais, as mulheres, dentre outros. Neste contexto é que se insere a Convenção sobre a Eliminação de todas as Formas de Discriminação Racial, adotada pela ONU em 1965, inaugurando, deste modo, o sistema especial de proteção 14.

Não há até o momento o consenso internacional suficiente para avançar na adoção de uma Convenção sobre a Eliminação da Discriminação por Orientação Sexual e Identidade de Gênero, visto que em mais de 70 países, práticas homossexuais ainda são criminalizadas.

Daí a urgência em se erradicar todas as formas de discriminação, baseadas na orientação sexual e identidade de gênero, que tenham como escopo a exclusão. O combate à discriminação é medida fundamental para que se garanta o pleno exercício dos direitos civis e políticos, como também dos direitos sociais, econômicos e culturais.

De toda sorte, em 2011, foi aprovada pela primeira vez uma resolução do Conselho de Direitos Humanos das Nações Unidas afirmando expressamente que os direitos LGBTI são direitos humanos. Em 2014, nova resolução foi reiterada pelo mesmo órgão, mas dessa vez houve maior adesão e menos resistência da

\footnotetext{
13 "garantias de não-discriminação e de igualdade em tratados internacionais de direitos humanos demandam igualdade tanto de facto e de jure. Igualdade de jure (ou formal) e igualdade de facto (ou substantiva) são conceitos diferentes, mas interligados" (Tradução livre). Disponível em: <http://docstore.ohchr.org/SelfServices/FilesHandler.ashx?enc=4slQ6QSmlBEDzFEovLCuW1AVC1NkPsgUedPIF1vfPMJpd X7m2Tx5L7detnk4aL8Sk\%2bOCLoaHsUFVMh6SviNU92S8cbmrriTaya9N9pSBR\%2b0tHil\%2fLewK1gfET938Og3y >. Acesso em: 23 nov. 2015.

14No campo do sistema especial de proteção, merecem também menção a Convenção sobre a Eliminação de todas as Formas de Discriminação contra a Mulher (1979), a Convenção sobre os Direitos da Criança (1990), a Convenção sobre a Proteção dos Direitos de Todos os Trabalhadores Migrantes e seus Familiares (1990) e a Convenção sobre os Direitos de Pessoas com Deficiência (2006).
} 
comunidade internacional, ainda que o documento tenha sofrido sete emendas antes de ser aprovado. Para Patrícia Gorisch, muito embora não tenha força vinculante originária, a resolução pode se tornar documento de observância obrigatória, após a aceitação explícita ou tácita dos Estados. Tendo em vista que o Brasil foi um dos Estados proponentes da resolução, considera-se que houve o aceite tácito, o que implica dizer que o território brasileiro assumiu a obrigação internacional de cumpri-la (GORISCH, 2014, p. 44 et seq).

Todavia, o combate à discriminação, como medida emergencial à implementação do direito à igualdade, não é, por si só, medida insuficiente. Faz-se necessário combinar a proibição da discriminação com políticas compensatórias que acelerem a igualdade como processo. Isto é, para assegurar a igualdade não basta apenas proibir a discriminação, mediante legislação repressiva. São essenciais as estratégias promocionais capazes de estimular a inserção e inclusão de grupos socialmente vulneráveis nos espaços sociais.

Os instrumentos internacionais que integram o sistema especial de proteção invocam uma proteção específica e concreta, que, transcendendo a concepção meramente formal e abstrata de igualdade, objetivam o alcance da igualdade material e substantiva, por meio, por exemplo, de ações afirmativas, com vistas a acelerar o processo de construção da igualdade em prol de grupos socialmente vulneráveis.

Considerando o alcance da proteção da igualdade e da proibição da discriminação no sistema global, transita-se para os sistemas regionais, com especial destaque aos direitos da diversidade sexual.

\section{A proteção dos direitos à diversidade sexual nos sistemas regionais europeu e interamericano de proteção dos direitos humanos}

Ao enfocar o modo pelo qual os direitos à diversidade sexual são incorporados pelos sistemas europeu e interamericano, constata-se que ambos os sistemas consagram a cláusula da igualdade e da proibição da discriminação.

A Convenção Europeia de 1950, em seu artigo 14, acolhe a cláusula da proibição da discriminação, ressaltando que:

O gozo dos direitos e liberdades reconhecidos na Convenção deve ser assegurado sem quaisquer distinções, tais como as fundadas no sexo, raça, cor, língua, religião, opiniões políticas ou outras, origem nacional ou social, pertença a uma minoria nacional, riqueza, nascimento ou qualquer outra situação.

A cláusula da proibição da discriminação é também enunciada enfaticamente pela Convenção Americana de 1969, ao estabelecer o dever dos Estados-partes de respeitar os direitos e liberdades nela 
reconhecidos e a garantir seu livre e pleno exercício, sem discriminação alguma, por motivo de raça, cor, sexo, idioma, religião, opiniões políticas ou de qualquer outra natureza, origem nacional ou social, posição econômica, nascimento ou qualquer outra condição social (artigo $1^{\circ}$ ). À cláusula da não discriminação soma-se o princípio da igualdade formal, por meio do qual "todas as pessoas são iguais perante a lei, tendo direito, sem discriminação alguma, à igual proteção da lei” (artigo 24). Assim como o Pacto Internacional dos Direitos Civis e Políticos, a Convenção Americana, ao admitir a suspensão de garantias e a restrição a direitos em casos de guerra, perigo público, ou outra emergência, explicitamente adverte que tal suspensão não poderá, de forma alguma, implicar discriminação fundada em motivos de raça, cor, sexo, idioma, religião ou origem social, enunciando, ainda, um núcleo inderrogável de direitos (artigo 27).

Ao reiterar o entendimento dos Comitês da ONU de Direitos Humanos, de Direitos Econômicos, Sociais e Culturais e sobre a Eliminação de todas as formas de Discriminação Racial, ressalta a Comissão Interamericana de Direitos Humanos que:

La no-discriminación, junto con la igualdad ante la ley y la igual protección de la ley sin ninguna discriminación constituye un principio fundante, básico, general y fundamental relativo a la protección internacional de los derechos humanos [...] La Comisión ha indicado que el principio de no discriminación es uno de los pilares de cualquier sistema democrático y una base fundamental del sistema de protección de los derechos humanos instaurado por la OEA. [...] En definitiva, la igualdad y la no-discriminación revisten un carácter de principio fundamental que subyace en todo el sistema internacional de los derechos humanos. Su negación implicaría la negación misma de este sistema en su totalidad ${ }^{15}$.

No sistema europeu emerge um vasto e significativo repertório jurisprudencial concernente aos direitos da diversidade sexual, que teve como agenda inaugural o combate à criminalização de práticas homossexuais consensuais entre adultos, no final da década de 80. Posteriormente, outras violações foram enfrentadas pelo sistema europeu, como a discriminação baseada em orientação sexual (no final da década de 90), casos relativos ao reconhecimento de direitos de transexuais (decisões favoráveis são proferidas a partir de 2002), adoção por homossexuais (decisões favoráveis são proferidas a partir de 2008) e o direito ao casamento (são os casos mais recentes decididos a partir de 2010).

\footnotetext{
15 "não-discriminação, juntamente com a igualdade perante a lei e igual proteção da lei sem qualquer discriminação, constitui um princípio fundante, básico, geral e fundamental relativo à proteção internacional dos direitos humanos (...) A Comissão indicou que o princípio da não discriminação é um dos pilares de qualquer sistema democrático e a base fundamental do sistema de proteção dos direitos humanos instituído pela OEA. (...) Em suma, a igualdade e a não discriminação se revestem do caráter de princípio fundamental subjacente a todo o sistema internacional de direitos humanos. Sua negação implicaria a negação desse sistema como um todo" (Tradução livre). Discursos e palestras durante a Sessão Especial de Reflexão e Análise sobre a natureza de uma futura Convenção Interamericana contra o Racismo e todas formas de Discriminação e Intolerância, realizada na sede da OEA em Washington, entre 28 e 29 de novembro de 2005. Disponível em: <http://www.oas.org/dil/esp/cajp.rdi15.orig.doc>. vol. 08, nº. 04, Número Especial. Rio de Janeiro, 2015. pp. 2613-2650 
Já no sistema interamericano, o leading case é o caso Atala Riffo y niñas vs. Chile, decidido pela Corte Interamericana em 24 de fevereiro de 2012, com relevante alusão à jurisprudência da Corte Europeia de Direitos Humanos sobre a matéria.

Corte Europeia de Direitos Humanos: casos envolvendo o direito à livre orientação sexual

Casos relativos à proibição da criminalização de práticas homossexuais consensuais

O primeiro precedente favorável sobre a questão LGBTI na Corte Europeia é o caso Dudgeon v. United Kingdom, por meio do qual o ativista gay Jeff Dudgeon denunciou leis que criminalizavam a homossexualidade na Irlanda do Norte à Comissão Europeia de Direitos Humanos em 1976, em razão de ter sido detido pela polícia e forçado a prestar depoimento sobre sua vida sexual por quatro horas e meia. Em 1980, a Comissão encaminhou a reclamação à Corte Europeia de Direitos Humanos que concluiu, no ano seguinte, ter sido violado o artigo $8^{\circ} \mathrm{da}$ Convenção Europeia que estabelece que a todos são garantidos o direito ao respeito à vida privada, à vida familiar, ao lar e à correspondência.

No caso Davis Norris v. Irlanda ${ }^{16}$, violação similar foi enfrentada e a Corte Europeia relembrou a jurisprudência sobre o envolvimento da prática sexual consensual entre homossexuais anteriormente mencionado. Em sentença proferida em 1988, a demanda foi acolhida, a fim de condenar a Irlanda, sob o fundamento de que as leis que criminalizam a homossexualidade configuram uma indevida ingerência estatal no direito ao respeito à vida privada, não justificável à luz do parágrafo $2^{\circ}$ do artigo $8^{\circ}$ da Convenção como uma medida "necessária em uma sociedade democrática".

De igual forma, no caso Modinos v. Cyprus, a Corte Europeia recebeu denúncia submetida pelo peticionário Alecos Modinos, presidente do "Liberation Movement of Homosexuals in Cyprus", sobre a criminalização de relações homossexuais consensuais entre adultos pela legislação penal de Cyprus. O pleito foi julgado procedente, condenando Cyprus também sob o fundamento de que tais leis constituiriam violação ao artigo $8^{\circ}$ da Convenção Europeia (direito ao respeito à vida privada), sendo uma injustificada ingerência estatal no direito ao respeito à vida privada.

\footnotetext{
${ }^{16}$ No mesmo sentido, ver casos L and V v. Áustria, Applications n. 39392/98 e 39829/98, Judgment 9.01.2003; B. B. v. Reino Unido, Application n. 53760/00, Judgment 10.02.2004; S.L v. Áustria, Application n. 45330/99, Judgment 9.01.2003. Disponível em: <http://hudoc.echr.coe.int>.
} 
Casos relativos à proibição da discriminação baseada em orientação sexual

Sobre essa temática, os casos Perkins e R. v. Reino Unido e Beck, Copp e Bazeley v. Reino Unido ${ }^{17}$ merecem destaque. Ambos referem-se à demissão de homossexuais das forças armadas no Reino Unido, após investigação de suas vidas privadas. Os peticionários, todos nacionais do Reino Unido, servindo nas forças armadas britânicas, foram demitidos com base em sua orientação sexual.

O Sr. Perkins servia junto à Royal Navy (Marinha Britânica) como assistente médico desde 1991, sendo descrito como competente e com muito bom caráter. Admitiu sua condição de homossexual em uma entrevista, após as autoridades navais terem recebido a informação concernente à sua orientação sexual. A Sra. R., por sua vez, ingressou na Royal Navy em 1990, estagiando como operadora de rádio. Em 1992, foi aprovada em um exame de qualificação profissional para operadora de rádio "primeira classe", sendo o seu caráter reconhecido como muito bom. Depois que uma colega -- para quem teria confidenciado ter tido uma breve relação lésbica com uma civil -informou às autoridades a respeito de sua homossexualidade, foi ela submetida a uma entrevista e demitida.

O Sr. Beck ingressou na Royal Air Force (Força Aérea Britânica) em 1976. Quando de sua demissão, em virtude de sua homossexualidade, era um analista de sistema de comunicações, com uma conduta profissional exemplar e altamente recomendado para promoção. Já o Sr. Copp ingressou no Army Medical Corps (Corpo Médico Militar) em 1978. Após receber uma promoção, sendo-lhe designado um posto na Alemanha em 1981, ele declarou sua homossexualidade, a fim de que não fosse separado de seu companheiro (um civil), tendo sido, por isso, demitido. O Sr. Bazeley entrou na Royal Air Force em 1985. Quando de sua demissão, era assistente de voo, considerado com bom potencial. Durante entrevista admitiu sua condição de homossexual, após sua carteira ter sido localizada contendo cartões de dois clubes homossexuais, tendo sido, por esse motivo, também demitido.

Sem qualquer sucesso, os peticionários adotaram todas as medidas internas, visando à reforma da decisão de demissão, sob o argumento de discriminação por orientação sexual. Alegaram ainda que a política do Ministério da Defesa do Reino Unido, relativa a não presença de homossexuais nas forças armadas, era "irracional" e contrária à Convenção Europeia de Direitos Humanos.

A Corte acolheu os dois casos, sob o fundamento de que a política de banir a presença de homossexuais nas forças armadas, mediante investigação da vida privada e sexualidade, constituía violação aos artigos 8 (direito ao respeito à vida privada) e 14 (proibição de discriminação) da Convenção Europeia. Argumentou que tal prática caracterizava uma flagrante discriminação e indevida ingerência no direito ao respeito à vida privada, não

\footnotetext{
${ }^{17}$ No mesmo sentido, ver casos Lustig-Prean e Beckett v. Reino Unido, Applications n. 31417/96 e 32377/96, Judgment 27.09.99; Smith and Grady v. Reino Unido, Application n. 33985/96, Judgment 27.09.99. Disponível em: <http:// hudoc.echr.coe.int>.
} vol. 08, nº. 04, Número Especial. Rio de Janeiro, 2015. pp. 2613-2650 
justificável à luz do parágrafo $2^{\circ}$ do artigo $8^{\circ}$ da Convenção como uma medida "necessária em uma sociedade democrática”.

No mesmo sentido, ao proibir a discriminação baseada em orientação sexual, cabe menção ao paradigmático caso Salgueiro da Silva Mouta v. Portugal envolvendo a denúncia de um peticionário português que se casou e teve uma filha. Divorciou-se da mulher e, desde então, passou a viver uma relação homossexual com um homem. Houve a disputa judicial a respeito do poder parental, sendo que, em grau de recurso, a exmulher obteve o poder parental, com base em decisão que se fundamentou na homossexualidade do peticionário.

A Corte Europeia condenou Portugal por afronta ao artigo $8^{\circ}$ (respeito ao direito à vida privada e familiar) e ao artigo 14 (proibição de discriminação), sob o argumento de que teria ocorrido violação ao princípio da proporcionalidade. Enfatizou que a decisão da justiça portuguesa, ao embasar-se fundamentalmente na homossexualidade do peticionário para negar-lhe o direito ao poder parental, estava a adicionar critério não previsto em lei, em direta afronta ao princípio da proporcionalidade, por "inexistir uma relação razoável entre os meios utilizados e o fim perseguido". Entendeu a Corte Europeia que não havia necessidade de fixar indenização pecuniária no caso, sendo a decisão em si mesma justa reparação pelo dano sofrido pelo peticionário.

Outro precedente emblemático enfrentado pela Corte Europeia, em decisão recente (2013), é o caso Eweida and others v. United Kingdom, que envolve a tensão entre o direito à liberdade religiosa e a proibição da discriminação em razão da orientação sexual. Os peticionários, sob fundamentação diversa, reclamaram à Corte, alegando que o direito interno do Reino Unido teria falhado em proteger adequadamente o direito à liberdade de manifestação de crença religiosa. No julgamento, a Corte Europeia afirmou que, muito embora o direito à liberdade de religião seja um dos fundamentos das sociedades pluralistas e democráticas, a manifestação de determinada crença deve ser limitada quando a expressão da fé colidir com os direitos das outras pessoas. Vale dizer, a Corte afirmou que em nome da liberdade religiosa não é admitida a violação de direitos; a liberdade de crença não pode suplantar o direito à livre manifestação da orientação sexual.

Casos relativos ao reconhecimento de direitos de transexuais

O caso Christine Goodwin v. Reino Unido ${ }^{18}$ tem como objeto o reconhecimento legal de transexual que realizou operação de mudança do sexo masculino para feminino, bem como tratamento diferenciado, especialmente, na esfera trabalhista, seguridade social, pensão e casamento no Reino Unido.

\footnotetext{
${ }^{18} \mathrm{Na}$ mesma direção, consultar I. v Reino Unido, Application n. 25680/94, Judgment 11.07.2002. Em sentido oposto, ver decisão da Corte Européia, em caso similar, proferida em 1990, concluindo que não restariam violados o artigo $8^{\circ}$ (por 10 a 8 votos) vol. 08, n. 04, Número Especial. Rio de Janeiro, 2015.pp. 2613-2650 2628
} 
A peticionária, com registro de nascimento do sexo masculino, viveu como mulher de 1985 a 1990, submetendo-se à cirurgia para mudança de sexo pelo serviço nacional de saúde. Denunciou a falta de reconhecimento legal da mudança de sexo, aludindo existir documentos nos quais ainda constam seu sexo como sendo masculino, o que lhe causa dificuldades, constrangimentos e humilhações. Acrescenta não ter, ademais, acesso à aposentadoria aos 60 anos (idade aplicável às mulheres). Como na esfera legal ainda é tida como homem, é obrigada a pagar contribuições até a idade de 65 anos. Também denuncia a violação ao direito ao casamento, restritivamente entendido como uma união entre um homem e uma mulher.

A Corte assumiu a necessidade de recorrer à uma interpretação dinâmica e evolutiva, de modo a aplicar a Convenção à luz das condições da realidade atual. Ressaltou que a falta de consenso na sociedade a respeito do status de um transexual (pós-operação) não pode ser compreendida como uma mera inconveniência ou formalidade. Não parece lógico, entendeu a Corte, permitir que a aludida cirurgia seja feita pelo sistema nacional de saúde e depois negar suas implicações legais e impacto jurídico. Tal situação tem gerado à peticionária consequências de alta relevância.

Afirmou a Corte existir uma tendência internacional em favor da aceitação social de transexuais, bem como do reconhecimento legal de sua nova identidade sexual (após a operação para a mudança de sexo). Argumentou que exceções têm sido admitidas no sistema de registro de nascimento como, por exemplo, na hipótese de adoção ou legitimação de filhos. Adicionar uma nova exceção relativa aos transexuais não colocaria em risco o sistema de registros como um todo, nem traria prejuízos a terceiros. Realçou ser a essência real da Convenção assegurar o respeito à dignidade humana e à liberdade, o que abrangeria, no século XXI, o direito dos transexuais ao desenvolvimento pessoal e à segurança física e moral de forma plena, tal como assegurado às demais pessoas. A zona intermediária em que os transexuais pós-operados se situam não é mais sustentável. Ponderou não haver qualquer suposto interesse público a caracterizar a chamada "margem de apreciação" para, eventualmente, legitimar a restrição do direito da peticionária. Na ponderação de bens, a Convenção mostrou-se absolutamente favorável ao direito da peticionária.

No que tange ao direito de casamento da peticionária, observou a Corte que, embora o artigo 12 da Convenção trate do direito ao casamento com expressa referência ao direito "do homem e da mulher" de se casar e de constituir uma família, tal previsão não obsta a pretensão da aplicante de casar-se e formar uma família - até porque não pode ser apenas considerado o critério puramente biológico para a definição dos sexos. A Convenção

tampouco o artigo 12 (por 14 a 4 votos) - caso Cossey v. Reino Unido, Application n. 10843/84, Judgment 27.09.1990. A mudança jurisprudencial revela avanços interpretativos da Corte Européia, com base na interpretação dinâmica e evolutiva. Disponível em: <http://hudoc.echr.coe.int>. 
deve levar em consideração as profundas mudanças sofridas pela instituição do casamento, bem como os extraordinários avanços da medicina e da ciência no campo da transexualidade. Com fundamento no direito ao respeito à vida privada ( $a r t i g o ~ 8^{\circ}$ da Convenção), a Corte sustentou que fatores biológicos não mais poderiam ser decisivos para negar o reconhecimento legal à mudança de sexo, nem tampouco privar a peticionária do direito ao casamento.

A Corte concluiu pela violação aos artigos $8^{\circ}$ (direito ao respeito à vida privada e familiar), 12 (direito ao casamento e à formação familiar) e 14 (proibição de discriminação), em prol do direito ao respeito à nova identidade sexual da peticionária.

Na mesma direção, destaca-se o caso Grant v. Reino Unido objetivando o reconhecimento legal da mudança de sexo de transexual, bem como a concessão de aposentadoria, considerando a idade mínima aplicável a mulheres, com fundamento no artigo $8^{\circ}$ da Convenção Europeia (direito ao respeito pela vida privada e familiar).

A peticionária é um indivíduo transexual, com 68 (sessenta e oito) anos, já submetido à operação para a mudança de sexo (masculino para feminino). Identifica-se como mulher desde 1963 para fins previdenciários, efetuando o pagamento das contribuições com base no critério aplicável às mulheres (até 1975, quando a diferença de valores foi abolida). Solicitou, assim, o direito à aposentadoria ao Estado quando alcançados os 60 anos, mas teria tido seu pedido indeferido, sob o entendimento de que a idade mínima, no caso, seria 65 anos (idade para o sexo masculino). Foi interposto recurso da decisão, sem qualquer sucesso.

Entendeu a Corte que, na hipótese, estaria caracterizada a violação ao artigo $8^{\circ}$ da Convenção Europeia, devido à falta de reconhecimento legal da mudança de sexo da peticionária. Adicionou inexistir qualquer justificativa para a negativa de tal reconhecimento, considerando a realização da operação para a mudança de sexo. Resultaria, assim, configurada a afronta ao direito ao respeito à vida privada da peticionária, com fundamento nos artigos $8^{\circ}$ e 14 da Convenção Europeia.

Casos relativos ao direito à adoção por homossexuais

No caso Fretté v. França, envolvendo adoção por homossexual, a Corte Europeia entendeu que a França, ao negar o direito de adoção por homossexual, não estaria a violar os artigos $8^{\circ}$ e 14 da Convenção, em sentença proferida em 26 de fevereiro de 2002. Na hipótese, após ter assumido sua homossexualidade, o "Paris Social Service Department" recomendou ao peticionário que não prosseguisse no processo de adoção. Ao final, indeferiu o pleito sob o argumento de que o peticionário não ofereceria um "modelo estável de maternidade" para a criança 
a ser adotada, tendo ainda dificuldades em avaliar o impacto decorrente da adoção de uma criança. A Corte sustentou que tal decisão estaria amparada na doutrina da "margem de apreciação" conferida ao Estado - que não poderia, contudo, simbolizar arbitrariedade. Concluiu que o tratamento diferenciado dado pela França ao caso não representaria violação aos artigos $8^{\circ}$ e 14 da Convenção Europeia (decisão tomada por 4 votos a 3). Somente entendeu a Corte estar violado o artigo $6^{\circ}$ da Convenção, por afronta ao devido processo legal, alegando falhas no curso do processo de adoção, que teriam implicado ofensa ao contraditório, em prejuízo do peticionário.

Já no caso E.B. v. França, sentenciado em 22 de janeiro de 2008, com base na interpretação dinâmica e evolutiva, concebendo a Convenção como um living instrument a ser interpretada à luz dos tempos atuais, a Corte Europeia condenou a França por indeferir a adoção por homossexual solteira, com fundamento na afronta aos artigos $8^{\circ}$ e 14 da Convenção. Sustentou que a legislação francesa permite a adoção por pesso as solteiras, o que estaria a permitir a adoção pela peticionária. Note-se que, no caso, o pleito de adoção foi formulado de forma individualizada e não pelo casal. Ao aludir ao precedente Salgueiro da Silva Moura v. Portugal, a Corte sustentou que a negativa da adoção na hipótese significaria injustificada interferência estatal na vida privada da peticionária, com violação adicional ao princípio da igualdade e da proporcionalidade. Ressaltou, ainda, que a decisão estaria a louvar a proteção do interesse maior da criança, uma vez que estariam comprovadas as qualidades e capacidades emocionais da peticionária ao longo do processo de adoção.

Caso relativos a direito de casamento de homossexuais

O caso Schalk and Kopf v. Austria compreende o direito ao casamento de homossexuais. Na hipótese, Shalk e Kopf mantinham uma união homoafetiva estável e demandaram o direito ao casamento. O pleito foi negado pelo Estado da Áustria, sob o argumento de que o casamento envolveria um contrato entre pessoas de sexos diferentes. Em sentença proferida em 24 de junho de 2010, a Corte Europeia - ainda que tenha reconhecido que a relação homoafetiva dos peticionários estaria abrangida pelo conceito de "família" - sustentou que a Convenção Europeia não estaria a obrigar o Estado a assegurar o direito ao casamento a casais homossexuais, não restando violados os artigos $8^{\circ}$ (direito ao respeito à vida privada e familiar), 12 (direito ao casamento) e 14 (proibição de discriminação). Adicionou que as autoridades nacionais seriam um locus mais adequado e apropriado para responder às necessidades sociais, considerando os aspectos culturais e sociais do casamento em diferentes sociedades.

No caso Oliari and Others v. Italy, decidido em 21 julho de 2015, a Corte Europeia novamente se pronunciou a respeito do matrimônio entre pessoas do mesmo sexo. Na situação em questão, 3 casais se 
insurgiram quanto ao fato de a legislação italiana não permitir o casamento homoafetivo tampouco qualquer espécie de união civil, o que caracterizaria discriminação com base na orientação sexual e violação do direito ao respeito à vida privada e familiar. A Corte Europeia entendeu que o comportamento de recusa do governo em reconhecer valor jurídico às relações homossexuais viola o artigo $8^{\circ}$ da Convenção (direito ao respeito à vida privada e familiar) e, portanto, condenou a Itália ao pagamento de indenização por danos morais no valor de 5 mil euros, a cada um dos peticionários.

Corte Interamericana de Direitos Humanos: caso relativo à proibição da discriminação baseada em orientação sexual

No sistema interamericano, merece destaque o leading case Atala Riffo y niñas vs. Chile, decidido pela Corte Interamericana em 24 de fevereiro de 2012. Este é o primeiro caso julgado pela Corte concernente à violação aos direitos à diversidade sexual, inexistindo, portanto, um universo de precedentes a permitir a criação de uma tipologia de casos - como ocorre no sistema europeu.

Ineditamente foi analisada a responsabilidade internacional do Estado em face do tratamento discriminatório e interferência indevida na vida privada e familiar da vítima Karen Atala devido à sua orientação sexual. O caso foi objeto de intenso litígio judicial no Chile, que culminou com a decisão da Corte Suprema de Justiça em determinar a custódia das três filhas ao pai, sob o argumento de que a Sra. Atala não deveria manter a custódia por conviver com pessoa do mesmo sexo, após o divórcio. No entender unânime da Corte Interamericana, o Chile violou os artigos 1을 parágrafo $1^{\circ}$ e 14 da Convenção Americana, por afrontar o princípio da igualdade e da proibição da discriminação.

À luz de uma interpretação dinâmica e evolutiva compreendendo a Convenção como um living instrument, ressaltou a Corte que a cláusula do artigo $1^{\circ}$, parágrafo $1^{\circ}$ caracteriza-se como aberta, de forma a incluir a categoria da orientação sexual, impondo aos Estados a obrigação geral de assegurar o exercício de direitos, sem qualquer discriminação.

Neste sentido, a Corte Interamericana recorreu ao caso Salgueiro da Silva Mouta vs. Portugal, sustentando que:

Respecto a la inclusión de la orientación sexual como categoría de discriminación prohibido, el Tribunal Europeo de Derechos Humanos ha señalado que la orientación sexual es "otra condición" mencionada en el artículo 14 del Convenio Europeo para la Protección de los Derechos Humanos e de las Libertades Fundamentales, el cual prohíbe tratos discriminatorios. En particular, en el caso Salgueira da Silva Mouta vs. Portugal, el Tribunal Europeo concluyo que la orientación sexual es un concepto que se encuentra cubierto por el 
Argumentou ainda a Corte que:

artículo 14 del Convenio Europeo. Además, reiteró que el listado de categorías que se realiza en dicho artículo es ilustrativa y no exhaustiva ${ }^{19}$.

A igualdade é inseparável da dignidade essencial de cada pessoa, frente a qual é incompatível toda situação que, por considerar superior um determinado grupo, implique tratá-lo com privilégios; ou que, a contrário senso, por considerá-lo inferior o trate com hostilidade, ou, de qualquer forma, o discrimine no gozo de direitos reconhecidos.

Enfatizou que o princípio da igualdade e da proibição de discriminação ingressou no domínio do "jus cogens" na atual etapa evolutiva do Direito Internacional, amparando a ordem pública nacional e internacional que permeia todo ordenamento jurídico. Concluiu que "nenhuma norma, decisão ou prática de direito interno, seja por parte de autoridade estatal, seja por particular, podem diminuir ou restringir direitos de pessoas com base em orientação sexual". Adicionou a Corte, sob pena de violação ao artigo $1^{\circ}$, parágrafo $1^{\circ}$ da Convenção:

a falta de consenso no interior dos países sobre o pleno respeito a direitos de minorias sexuais não pode ser considerada como um argumento válido para negar-lhes ou restringirlhes direitos humanos ou perpetuar ou reproduzir discriminações históricas ou estruturais que estas minorias tenham sofrido.

Quanto ao argumento da Corte Suprema de Justiça do Chile de que haveria "el derecho preferente de las menores (de edad) a vivir y desarrollarse en el seno de una familia estructurada normalmente y apreciada en el medio social, según el modelo tradicional que le es propio"20 uma vez mais a Corte Interamericana recorreu ao aludido precedente da Corte Europeia de Direitos Humanos, sob o argumento de que:

En el caso Salgueiro da Silva Mouta vs. Portugal, el Tribunal Europeo consideró que la decisión de un Tribunal nacional de retirar de un padre homosexual la custodia de sua hija menor de edad, con el argumento que la niña debería vivir en una familia portuguesa tradicional, carecía de relación razonable de proporcionalidad entre la medida tomada (retirada de custodia) y el fin perseguido (protección del interés superior de la menor de edad $)^{21}$.

Acrescentou, ademais, o argumento do necessário respeito à vida privada, o que estaria a abarcar a identidade física, social, bem como o desenvolvimento pessoal, a autonomia pessoal e o direito de estabelecer e desenvolver relações com outras pessoas do mesmo sexo. Sustentou, na hipótese, a violação pelo Chile do direito

\footnotetext{
19 "Quanto à inclusão da orientação sexual como categoria de discriminação proibida, o Tribunal Europeu de Direitos Humanos afirmou que a orientação sexual é "outra condição" mencionada no artigo 14 da Convenção Europeia para a Proteção dos Direitos do Homem e das Liberdades Fundamentais, a qual próbe o tratamento discriminatório. Em particular, no caso Salgueira da Silva Mouta vs. Portugal, o Tribunal Europeu concluiu que o conceito de orientação sexual está abarcado pelo artigo 14 da Convenção. Ademais, reiterou que a lista de categorias que é feita nesse artigo é exemplificativa e não exaustiva" (Tradução livre).

20 "Há supremacia do direito das menores de idade em viver e desenvolver-se no seio de uma família normalmente estruturada e apreciada no meio social, segundo o modelo que lhe é próprio" (Tradução livre).

21 "No caso Salgueiro da Silva Mouta vs. Portugal, o Tribunal Europeu considerou que a decisão de um tribunal nacional de retirar de um pai homossexual a guarda de sua filha menor de idade, argumentando que a criança deve viver em uma família tradicional portuguesa, não tinha relação razoável de proporcionalidade entre a medida tomada (retirada de guarda) e a finalidade prosseguida (a proteção do interesse superior da menor de idade)" (Tradução livre).
} 
consagrado no artigo 11 da Convenção Americana concernente à proteção à honra e à dignidade, o que estaria a envolver o respeito à vida privada e a proibição de ingerência abusiva ou arbitrária na vida privada.

Consignou a Corte, ainda, que não é possível restringir ou diminuir direitos de uma pessoa, considerando a sua orientação sexual, porquanto esta encontra respaldo no direito à livre autodeterminação, o que garante ao indivíduo a livre escolha de opções e circunstâncias que lhe dão sentido à vida, segundo suas próprias conviç̧ões. Isso porque, segundo a Corte, a Convenção Americana não traz um modelo fechado ou tradicional de família, mas, ao revés, entende que o conceito de família é amplo e abarca outros laços familiares baseados no afeto.

De outro lado, a decisão enfatizou que o princípio do melhor interesse da criança não pode ser invocado para gerar uma discriminação por orientação sexual contra os próprios pais e tampouco pode se basear em especulações, presunções, estereótipos e considerações generalizadas de características dos pais ou preferências culturais pertinentes a conceitos tradicionais de família, devendo os riscos e danos ser concretamente provados.

Ainda que este seja o primeiro e único caso decidido pela Corte Interamericana a respeito da discriminação por orientação sexual, importa realçar que, nos termos da resolução da Assembleia Geral da OEA, de 7 de junho de 2011 (resolução AG/RES 2653 - XLI-0/11), os Estados condenam toda e qualquer discriminação e violência fundada em orientação sexual, encorajando a adoção de políticas públicas de combate à discriminação por orientação sexual e para a proteção de suas vítimas.

Por sua vez, em 03 de novembro de 2011, a Comissão Interamericana de Direitos Humanos estabeleceu uma "Unidad para los derechos de las lesbianas, los gays y las personas trans, bisexuales e intersexo"22. Para a Comissão Interamericana:

[... ] la orientación sexual, la identidad de género y la expresión de género son componentes fundamentales de la vida privada de las personas. La Comisión Interamericana ha enfatizado que el derecho a la vida privada garantiza esferas de la intimidad que el Estado ni nadie puede invadir, tales como la capacidad para desarrollar la propia personalidad y aspiraciones y determinar su propia identidad, así como campos de actividad de las personas que son propios y autónomos de cada quien, tales como sus decisiones, sus relaciones interpersonales y familiares y su hogar ${ }^{23}$.

\footnotetext{
22 "Unidade para os Direitos de lésbicas, gays e pessoas trans, bissexuais e intersexuais.

23 “[...], a orientação sexual, a identidade de gênero e a expressão de gênero são componentes fundamentais da vida privada das pessoas. A Comissão Interamericana salientou que o direito à vida privada proporciona esferas de intimidade que nem o Estado nem ninguém pode invadir, tais como a capacidade de desenvolver a sua personalidade e aspiração e portar a sua própria identidade, assim como campos de atividade das pessoas que lhe são próprios e autônomos, como suas decisões, suas relações interpessoais e familiares e sua casa" (Tradução livre). Ver mais em: Estudio elaborado por la Comisión Interamericana de Derechos Humanos "CIDH” en cumplimiento de la resolución AG/RES. 2653 (XLI-O/11): Derechos Humanos, Orientación Sexual e Identidad de Género. Disponível em: < http://www.oas.org/dil/esp/CP-CAJP-INF_166-12_esp.pdf>.
} 
Por derradeiro, destaca-se que as Cortes Regionais não exercem o papel de $4^{\circ}$ grau de jurisdição e, embora as suas jurisprudências revelem que o direito à diversidade sexual encontra respaldo em convenções e tratados de direitos humanos, para se chegar às instâncias protetivas dos sistemas global e regionais, condição é, em regra, o esgotamento prévio dos instrumentos protetivos disponíveis no âmbito doméstico.

Por essa razão, revela-se imprescindível analisar quais são as demandas que chegam ao Poder Executivo, Legislativo e Judiciário, bem como qual é a resposta que o Estado brasileiro oferece às questões atinentes à população LGBTI, sobretudo, após o reconhecimento das uniões homoafetivas pelo Supremo Tribunal Federal.

\section{A PROTEÇÃO DOS DIREITOS DA POPULAÇÃO LGBTI NA ORDEM JURÍDICA BRASILEIRA}

No plano interno, a promulgação da Constituição de 1988 demarcou a emergência de um novo paradigma no sistema jurídico brasileiro, refletindo o processo de reconhecimento do indivíduo como o principal destinatário de toda a ordem jurídica. Não obstante, além de ter textualmente internacionalizado alguns dos direitos humanos previstos na Declaração Universal de 1948, inaugurou a reintrodução do regime democrático no país. A Lei Maior reflete, portanto, uma nova perspectiva normativa, todo ela voltada para a realização dos direitos do cidadão, rompendo em definitivo com os antigos Atos Institucionais que legitimaram as barbáries perpetradas no período da ditadura militar.

Nesse contexto, destacam-se os $\$ \$ 2^{\circ}$ e $3^{\circ}$ do art. $5^{\circ}$ da Carta da República que introduziu verdadeira cláusula de abertura constitucional, reconhecendo, portanto, a limitação da soberania nacional, ao sujeitar o sistema jurídico brasileiro aos tratados internacionais sobre direitos humanos que o Brasil seja parte. Vale dizer, o dispositivo inaugurou o chamado "bloco de constitucionalidade", admitindo a supremacia dos direitos humanos sob a ordem doméstica.

Portanto, a partir do advento dos princípios da isonomia e da proibição da discriminação de qualquer ordem, somados à cláusula de proteção da personalidade, por meio da proteção da dignidade humana, qualificada como fundamento da República Federativa do Brasil, o texto constitucional se tornou a principal fonte de fundamento para as questões pertinentes à população LGBTI no âmbito doméstico.

No que diz respeito à constituição familiar, ressalta-se que a Lei Maior consagrou o princípio da afetividade, tutelando o afeto dos indivíduos como elemento caracterizador da família, o que the conferiu uma outra concepção, rompendo definitivamente com a lógica ultrapassada da família transpessoal, patriarcal e matrimonializada prevista no Código Civil de 1916. 
O texto constitucional estabeleceu, ainda, especial proteção à família, considerando-a como base da sociedade, tal qual prevê a Declaração de 1948 no art. 16.3: "A família é o núcleo natural e fundamental da sociedade e tem direito a proteção da sociedade e do Estado".

Para Maria Berenice Dias, o novo texto constitucional permitiu que todas as espécies de vínculos com base no afeto tivessem feição de família e merecessem proteção do Estado, sobretudo, face à cláusula de proteção da dignidade da pessoa humana, consagrada como pétrea na Constituição Federal de 1988 (DIAS, 2009, p. 129).

De outro lado, esclarece Luiz Edson Fachin (2004, p. 4) que a transformação legislativa ocorrida, trazendo elementos valorativos da pessoa, considerada em sua dignidade humana, é a maneira pela qual se efetiva o real Estado de Direito. Acrescenta, ainda, que "sob o pálio da CF 88, diversos aspectos fundamentais redirecionaram a jurisprudência, a doutrina e a legislação. Por isso, a reaviventação do Direito Civil da Família compreende (agora) o Direito Constitucional da Família” (FACHIN, 2004, p. 15).

Dessa forma, as famílias formadas por pessoas de igual sexo passaram a ser timidamente admitidas pelo direito brasileiro, no final do século XX, como meras sociedades de fato, sendo no campo dos Direitos das Obrigações que questões advindas dessas relações eram analisadas, justificando-se, assim, a partilha e a herança. Quando não existia patrimônio a ser divido, aplicava-se a ideia de relação laboral, indenizando-se o serviço doméstico, fazendo crer a ideia de prestação de serviços (DIAS, 2009, p. 124).

A aplicação da Carta Constitucional pelos Tribunais veio a ensejar que a apreciação de conflitos oriundos das relações afetivas entre pares do mesmo sexo deveria transitar do campo do Direito das Obrigações (já que o caráter não patrimonial pareceu estar bastante evidente) para a esfera do Direito de Família.

Percebeu-se, assim, que os grupos familiares existentes vão muito além dos modelos codificados, sendo o afeto o critério responsável pela constituição, transformação e extinção dos laços familiares, em detrimento do modelo único patriarcal que se voltava para o patrimônio.

Todavia, esse reconhecimento não produzia efeitos para toda a população LGBTI. Para usufruírem desse direito, os pares de igual sexo necessitavam pedir a chancela do Estado, pois o exercício do direito à diversidade sexual não estava garantido automaticamente. Em muitos Tribunais, inclusive, os entendimentos sobre a matéria eram dissonantes. Essa circunstância deu origem ao ajuizamento de duas ações perante o Supremo Tribunal Federal: a Ação Direta de Inconstitucionalidade no 4277-DF e a Arguição de Descumprimento de Preceito Fundamental no 132-RJ.

Ao serem julgadas conjuntamente, em maio de 2011, a Suprema Corte brasileira reconheceu a proibição de discriminação, seja no plano do sexo (homem e mulher), seja no plano da orientação sexual, realçando que o 
direito à manifestação da sexualidade faz parte da autonomia individual da cada pessoa, tutelada constitucionalmente no plano da intimidade e da vida privada. A Corte afirmou, ainda, que a norma elencada no art. 226, $\$ 3^{\circ}$ da Constituição, ao afirmar o reconhecimento da união estável entre homem e mulher como entidade familiar, não poderia ser interpretada de forma reducionista, em virtude da proibição do preconceito como capítulo do constitucionalismo fraternal.

De toda sorte, à medida que a Suprema Corte brasileira apenas reconheceu a validade jurídica da união civil homoafetiva, silenciando-se a respeito de diversos outros temas decorrentes dessa judicialização, os casais homoafetivos continuam enfrentando, na prática, barreiras para exercer plenamente o direito à diversidade sexual, inclusive, perante o próprio Poder Judiciário.

O primeiro e mais contundente desafio enfrentado pelas minorias sexuais diz respeito à possibilidade de conversão da união estável entre pares do mesmo sexo, chancelada pelo Supremo Tribunal, em casamento. Isso porque o citado art. $226, \$ 3^{\circ}$ do texto constitucional estabelece também que a lei deve facilitar a conversão da união estável em casamento.

Muito embora o Superior Tribunal de Justiça tenha reconhecido o direito à conversão da união estável em casamento, em julgamento com efeitos restritos às partes do processo (Recurso Especial no 1.183.378/RS), o Conselho Nacional de Justiça (CNJ) fundamentou-se nesse precedente para editar a Resolução no 175 , em maio de 2013, garantindo a vedação da recusa de habilitação para o casamento de casais homossexuais.

De qualquer forma, a Corte Suprema terá a oportunidade de manifestar-se sobre essa questão e chancelar a possibilidade de conversão em casamento, porque o Partido Social Cristão se insurgiu contra a Resolução no 175/2013 do CNJ, por meio da Ação Direta de Inconstitucionalidade, ajuizada em 7 de junho de 2013 e autuada sob o número 4966.

Ainda que não tenha sido pacificada a questão, a Corregedoria-Geral de Justiça dos Tribunais de Justiça dos Estados tem criado resoluções/instruções aos cartórios regulamentando essa conversão na própria via extrajudicial. Não fosse esse ato de vigor intelectual, o direito à conversão da união estável em casamento somente seria reconhecido por meio de eventual decisão judicial favorável, o que demandaria o ajuizamento de ação, sujeitando às partes a longa espera por uma resposta judicial, sem mencionar, é claro, a possibilidade de o feito ser julgado por magistrado ou ter a participação de membro do Ministério Público com entendimento dissidente, o que retardaria ainda mais o processo de conversão. Nesse sentido, recorda-se a série de Reclamações ajuizadas no Supremo Tribunal Federal visando à preservação do entendimento pacificado pela Corte em 2011. 
Outra questão que desperta entendimentos dissonantes é a adoção. Muito embora o Estatuto da Criança e do Adolescente não enuncie qualquer proibição sobre a possibilidade de adoção por casais homoafetivos, na prática, na fila da adoção, testemunha-se que a pretensão de adoção por esses cônjuges depende unicamente da vontade do operador do direito no caso concreto. Por essa razão, muitos casais pleiteiam a adoção individualmente, o que traz inúmeros prejuízos à criança, na medida em que fica completamente desamparada em relação ao outro parceiro que não tem responsabilidade ou deveres decorrentes do poder familiar.

Nesse sentido, muito atento à realidade do país e, principalmente, ao número de crianças em abrigos consideradas inadotáveis, porque não são objeto de desejo de uma grande maioria que aguarda o processamento da adoção, o Superior Tribunal de Justiça reiterou, em recente julgamento, proferido em 18/08/2015, no Recurso Especial $\mathrm{n}^{\circ}$ 1.540.814-PR, o entendimento da Corte sobre o tema, confirmando a possibilidade de adoção para casal formado por pessoas do mesmo sexo.

Ocorre que, esse cenário relava duas situações. A primeira positiva, porque manifesta o posicionamento favorável da Corte em relação à adoção por casal homoafetivo. De outro lado, experimenta-se a mesma problemática em relação à falta de efeito vinculante da decisão que validou a conversão da união estável em casamento. Vale dizer, a falta do comando obrigatório para os demais órgãos jurisdicionais do país impede a implementação plena do direito de adotar e formar uma família. Com efeito, faz necessário observar a questão a partir de uma rede de proteção ampla, irrestrita e compartilhada da criança, nos exatos termos em que propõem os tratados internacionais sobre os direitos da criança.

Nessa perspectiva, a família pluriparental também precisa ser reconhecida pelo direito, a fim de efetivar essa rede de proteção à criança, que não pode ser discriminada em razão da orientação sexual dos pais ou, ainda, pelo formato familiar plural, comum em decorrência dos avanços científicos no campo da reprodução humana assistida.

Ainda no contexto familiar, há questão que repercute no âmbito laboral. Com o reconhecimento das famílias homoafetivas, emerge a necessidade de revisão da licença "maternidade", porque na forma como está atualmente prevista, só confere direito à mulher, excluindo os casais formados por dois homens e, na hipótese de serem duas mulheres, apenas uma delas pode receber o benefício.

Em relação aos transexuais, as demandas principais ainda são relativas ao direito à saúde e à retificação do registro civil. Os serviços de saúde ainda não estão preparados para recepcionar pessoas transexuais, porque os profissionais que atuam no sistema ainda manifestam muito preconceito, o que resulta na exclusão dessa que é uma das categorias mais vulnerários da comunidade LGBTI. Não bastasse isso, o processo de redesignação do 
sexo no Brasil, realizado pelo Sistema Único de Saúde, nos termos da Portaria no 2.803/2013, é ainda bastante burocrático e não contempla a previsão de retificação automática de documentos relativos ao registro civil. Isto é, após a realização da cirurgia, ainda se faz necessário o ajuizamento de medida judicial para realização da troca do nome e designativo do sexo nos documentos pessoais, matéria ainda bastante controvertida nos Tribunais ${ }^{24}$.

Nesse sentido, destaca-se, ainda, que a falta de visibilidade social dos transexuais, além de contribuir para marginalização desse segmento, contribui para a anulação de direitos. Na medida em que esses indivíduos são discriminados por não refletirem o estereótipo dos documentos oficiais, acabam se tornando seres inexistentes na ordem jurídica ${ }^{25}$.

No que diz respeito ao direito à intimidade e não ingerência na vida privada das pessoas LGBTI, atualmente não há qualquer garantia sobre a confidencialidade de informações envolvendo a diversidade sexual no âmbito laboral, seja no momento da contratação, para evitar a discriminação, seja na oportunidade em que se pleiteia a extensão de benefícios trabalhistas ao parceiro de trabalhador LGBTI como, por exemplo, o plano de saúde.

No tocante à discriminação em razão da orientação sexual e da identidade de gênero, não há, na legislação penal brasileira, crime específico prevendo a responsabilidade do agressor e tampouco causas de aumento de pena de crimes motivados com essa finalidade, o que contribui para a impunidade daqueles que violam direitos humanos LGBTI. De outro lado, o Código Penal Militar ainda estabelece o crime de pederastia no âmbito das forças armadas, o que exclui o ingresso de pessoas LGBTI do serviço militar ou das carreiras nas forças armadas. Quanto ao tema, vale dizer que o próprio Supremo Tribunal Federal, quando do julgamento do Habeas Corpus no 79.285/RJ, reconheceu a constitucionalidade do tipo penal sobre a pederastia, previsto no Código Penal Militar. Todavia, a jurisprudência dos Tribunais Federais tem reconhecido o direito à reintegração, em casos de nulidade de desincorporação, e o direito à pensão para o companheiro sobrevivente, no caso de morte de parceiro militar ${ }^{26}$.

\footnotetext{
${ }^{24}$ A respeito verificar os enunciados no 42 e 43 aprovados pela I Jornada de Direito da Saúde, promovida pelo Conselho Nacional de Justiça, entre os dias 14 e 16 de maio de 2014, disponível em: $<$ http://www.cnj.jus.br/images/ENUNCIADOS_APROVADOS_NA_JORNADA_DE_DIREITO_DA_SAUDE_\%20PLE NRIA_15_5_14_r.pdf>.

${ }^{25}$ Tramita, perante o Supremo Tribunal Federal, o Recurso Extraordinário no 845779 , com repercussão geral reconhecida, em que se discute o direito dos transexuais de serem socialmente aceitos de acordo com a sua identidade de gênero, inclusive, no que diz respeito à utilização de banheiros públicos. Disponível em: <http://www.stf.jus.br/portal/processo/verProcessoAndamento.asp?incidente=4657292>.

${ }^{26}$ Nesse sentido, ver a jurisprudência do Tribunal Regional Federal da Segunda Região: Apelação Cível no $0033834-$ 70.1998.4.02.0000, da Oitava Turma Especializada, Relalor Juiz Convocado Marcelo Pereira. Disponível em: <http://www10.trf2.jus.br/consultas/?movimento=cache\&q=cache:-
} 
No sistema presidiário, por sua vez, não se verifica qualquer atenção à orientação sexual e à identidade de gênero do encarcerado, o que legitima a ocorrência da discriminação e, não raras vezes, gera risco a sua integridade física e psíquica.

No âmbito do Poder Executivo, as minorias sexuais carecem de políticas públicas na área da educação, a fim de esclarecer e informar a sociedade sobre o direito à diversidade sexual e à inclusão social, a permitir que a população LGBTI seja inserida no laço social e possa desfrutar dos mesmos direitos que a maioria dominante já usufrui.

$\mathrm{Na}$ esfera legislativa, além de enfrentar a falta de legislação específica que possibilite o exercício de direitos, há o desafio de superar os fundamentalismos religiosos que constantemente têm impedido a concretização de avanços nessa área. Em 14 de maio de 2015, foi desarquivado um Projeto de Decreto Legislativo apresentado em 2011, cujo objetivo é sustar os efeitos da decisão do Supremo Tribunal Federal proferida na Ação Direta de Inconstitucionalidade (ADI) 4277 e Arguição de Descumprimento de Preceito Fundamental (ADPF) 132 e 178, que reconheceu a entidade familiar da união entre pessoas do mesmo sexo ${ }^{27}$.

Muito embora os desafios à plena implementação do direito à diversidade sexual encontrem barreiras mais evidentes no sistema jurídico, outros fatores como, por exemplo, a ordem econômica global e os fundamentalismos religiosos, também têm repercutido na efetividade desse direito, como será abordado no próximo capítulo.

\section{DESAFIOS À PLENA IMPLEMENTAÇÃO DOS DIREITOS HUMANOS LGBTI}

A implementação do direito à diversidade sexual demanda mudança legislativa, mediante a criação de dispositivos legais que revelem as peculiaridades e as especificidades da população LGBTI. Nesse sentido, destaca-se a importância da adoção de um Estatuto da Diversidade Sexual, cujo objetivo é a readequação legislativa de todo o sistema brasileiro tendo como referência a plena observância dos direitos humanos LGBTI.

CW9r7A7N6kJ:trf2nas.trf.net/iteor/TXT/RJ0108810/1/119/285046.rtf+\&site=v2_jurisprudencia\&client=v2_index\&proxyst ylesheet=v2_index\&lr=lang_pt\&ie=UTF-8\&output=xml_no_dtd\&access=p\&oe=UTF-8 $>$, e Apelação Cível no 2009.51.01.029808-4, da Sétima Turma Especializada, Relator Des. Federal Reis Friede. Disponível em: <http://www10.trf2.jus.br/consultas/?movimento=cache\&q=cache:dNvXn3G00noJ:trf2nas.trf.net/iteor/TXT/RJ0108710/1/ 165/432611.rtf \&site=v2_jurisprudencia\&client=v2_index\&proxystylesheet=v2_index\&lr=lang_pt\&ie=UTF-

8\&output $=x m l \_n o \_d t d \& a c c e s s=p \& o e=U T F-8>$.

27 a acompanhamento do PDC no 325/2011 encontra-se disponível no site: <http://www.camara.gov.br/proposicoesWeb/fichadetramitacao?idProposicao=511719>. 
Todavia, a problemática da efetividade do direito à diversidade sexual demonstra que a necessidade de alteração e/ou criação de novas leis não é suficiente. Faz-se necessário o enfrentamento de 3 desafios centrais à plena implementação do direito à diversidade sexual:

1. A falta de reconhecimento dos direitos LGBTI como direitos humanos;

2. O processo de globalização econômica, e

3. A emergência dos fundamentalismos religiosos.

\section{A afirmação dos direitos à diversidade sexual como direitos humanos}

A orientação sexual e a identidade de gênero são expressões da condição humana. A plena realização da vida somente se implementa se o indivíduo tem a oportunidade de exercer também a sua sexualidade.

A partir dessa premissa, faz necessário compreender o direito à livre expressão da orientação sexual e o direito à livre vivência da identidade de gênero como direitos que decorrem diretamente do direito à vida, tutelado no plano da vida privada e da intimidade, e do direito à liberdade individual, consagrados pelo Direito Internacional dos Direitos Humanos, em especial, pela Declaração Universal dos Direitos Humanos de 1948, pelo Pacto Internacional de Direitos Civis e Políticos, pelo Pacto Internacional de Direitos Econômicos, Sociais e Culturais, ambos de 1966, e pela Declaração de Viena de 1993.

Nas Nações Unidas, destaca-se que já houve, mais de uma vez, o reconhecimento de que os direitos LGBTI são direitos humanos: no caso Toonen vs. Australia (1994) pelo Comitê de Direitos Humanos, na Recomendação Geral no 16 e no 20 do Comitê dos Direitos Econômicos, Sociais e Culturais e, mais recentemente, pelas resoluções de 2011 e 2014 do Conselho de Direitos Humanos.

O direito à diversidade sexual e, como decorrência, a proibição da discriminação por orientação sexual e identidade de gênero, integra, assim, o Direito Internacional dos Direitos Humanos. Essa afirmação, porém, ganharia mais força no cenário global com a adoção de uma Convenção sobre a Eliminação da Discriminação por Orientação Sexual e Identidade de Gênero.

Não há, até o momento, o consenso internacional suficiente para avançar na adoção de um tratado multilateral sobre essa temática, à medida que 75 países ainda criminalizam as práticas homossexuais, o que representa 39\% dos Estados que fazem parte das Nações Unidas, conforme aponta o Relatório, de maio de 2015, da International Gay and Lesbian Association.

Daí a urgência em se erradicar todas as formas de discriminação, baseadas na orientação sexual e identidade de gênero, que tenham como escopo a exclusão. $\mathrm{O}$ combate à discriminação é medida fundamental vol. 08, n. 04, Número Especial. Rio de Janeiro, 2015. pp. 2613-2650 
para que se garanta o pleno exercício dos direitos civis e políticos, como também dos direitos sociais, econômicos e culturais.

De toda sorte, o combate à discriminação, como medida emergencial à implementação do direito à igualdade, não é, por si só, medida suficiente. Faz-se necessário combinar a proibição da discriminação com políticas compensatórias que acelerem a igualdade como processo. Isto é, para assegurar a igualdade não basta apenas proibir a discriminação, mediante legislação repressiva. São essenciais as estratégias promocionais capazes de estimular a inserção e inclusão de grupos socialmente vulneráveis nos espaços sociais, com vistas a acelerar o processo de construção da igualdade.

Nesse fluxo, a consagração dos direitos LGBTI como direitos humanos viria induvidosamente contribuir com a implementação desse processo, sobretudo, porque na qualidade de direitos humanos impactariam diretamente a ordem jurídica interna, em razão da ruptura do conceito de soberania estatal absoluta, perpetrada após a aderência a tratados e convenções no âmbito internacional.

Vale dizer, ainda, que na qualidade de um dos proponentes da Resolução que foi aprovada pelo Conselho de Direitos Humanos das Nações Unidas, em 2014, a qual consolida a extensão dos direitos humanos aos direitos relativos à orientação sexual e à vivência de gênero, o Brasil está sujeito a cumpri-la e, portanto, deve ser intensificada a atenção às minorias sexuais na agenda política do país, sob pena de responsabilização no cenário internacional.

\section{A globalização econômica e seus efeitos para proteção dos direitos humanos}

Um segundo desafio atém-se ao impacto da globalização econômica em relação aos direitos humanos.

Com efeito, o desenvolvimento de novas tecnologias em matéria de transporte e telecomunicações, sobretudo nos últimos 20 anos, transformou a sociedade internacional, na expressão do filósofo Marshall Mcluhan (2011, p. 74), em uma aldeia global, na medida em que as fronteiras entre os países se tornaram menos distantes e os fenômenos locais passaram a ser sentidos em todo o globo.

Os Estados passaram, assim, a enfrentar problemas que não são mais resolvidos a partir dos instrumentos domésticos, a exemplo do que ocorre com a proteção dos direitos humanos, as questões ambientais e a regulação do comércio. Isto é, o plano nacional não mais consegue atender toda a realidade em que se inserem os indivíduos e classes, nações e nacionalidades, culturas e civilizações, o que vem a exigir uma regulamentação internacional para problemas que passam a ser globais. 
Para Richard Falk, o processo de globalização impulsionou a orientação política do Estado para o exterior, passando as nações a funcionarem como instrumento de forças de mercado regionais e globais, objeto de manipulação por corporações, bancos transnacionais e agentes financeiros (FALK, 1999, p. 77).

Esse cenário é, em grande medida, resultado do contexto geopolítico pós-guerra fria, a partir do qual o processo de globalização se intensificou, produzindo intensas transformações nas relações, processos e estruturas econômicas, políticas, demográficas, geográficas, históricas, culturais e sociais que se desenvolvem no âmbito mundial, as quais vem impactando e até mesmo se sobrepondo às relações, processos e estruturas nacionais.

No plano econômico, em especial, a globalização serviu como difusor das práticas neoliberais levadas a efeito na década de 80 pelos governos de Margareth Thatcher, na Inglaterra, e de Ronald Reagen, nos Estados Unidos. Na América do Sul, essas políticas são verificadas ainda na década de 70, no Chile, com o regime de Pinochet, e desembarcam no Brasil na década de 90 com os governos de Fernando Collor e Fernando Henrique Cardoso. É também dos anos 90 o chamado Consenso de Washington, que, a seu turno, realizou inúmeras exigências de reformas políticas e ajustes econômicos, a fim de consolidar a implementação do neoliberalismo nos países sul-americanos.

Ocorre que, o ideário neoliberal surgiu com o objetivo de combater a crise do Estado de Bem-Estar Social, opondo-se à ideia de pleno emprego e à regulação da economia. Com efeito, buscava a padronização de valores da cultura para ampliar o consumo, o que trouxe o aumento da dependência financeira da economia global, concentrou riquezas, gerando pobreza e aumentou as diferenças culturais, sociais, políticas e econômicas entre os países do Norte e do Sul, excluindo as populações vulneráveis.

Nesse contexto, percebe-se que quanto mais determinante for a lógica neoliberal para o Estado, mais desigual será a sociedade, menos espaço haverá para a implementação dos direitos humanos e, por conseguinte, a tônica que reclama o respeito à livre expressão da sexualidade e da identidade de gênero dos indivíduos continuará sem voz, sendo invisibilizada. Por isso, faz-se necessário compreender o processo de globalização descendente, na expressão de Richard Falk, ou de cima para baixo, na concepção de Boaventura de Sousa Santos (2001), como obstáculo à concretização dos direitos humanos LGBTI.

Torna-se imprescindível, portanto, a implementação de meios que busquem evitar as implicações negativas da política de governança global, tais como a criação e o reforço do movimento denominado globalização ascendente e a consolidação de um direito e de uma governança nos âmbitos regional e global (FALK, 1999, p. 89). 
Nesse sentido, deve também emergir a consciência sobre o forte impacto que as políticas econômicas têm sobre as economias locais e também sobre a implementação da igualdade material na perspectiva do reconhecimento de identidades, da visibilização da diferença. O Banco Mundial e do Fundo Monetário Internacional (FMI) devem levar em consideração a dimensão humana de suas atividades, rompendo com a tensão entre a proteção dos direitos humanos, sobretudo, os direitos econômicos, sociais e culturais e a política institucional que submete países em desenvolvimento a modelos de ajuste estrutural incompatível com aqueles direitos. Há de reforçar a democratização, a transparência e a accountability dessas instituições que ditam regras globais a partir do consenso entre poucos.

No âmbito privado, as empresas, especialmente as multinacionais, devem considerar a ótica dos direitos humanos, devendo seus empréstimos ser condicionados à proteção dos direitos humanos, com a imposição de sanções comerciais quando violarem direitos sociais, dentre outras medidas.

A despeito dos fatores nefastos da globalização econômica para os países em desenvolvimento, há outro desafio a ser enfrentado na busca da plena implementação do direito à diversidade sexual, que exclui as minorias sexuais tanto quanto às práticas neoliberais: os fundamentalismos religiosos.

\section{A secularidade estatal e os fundamentalismos religiosos}

O Estado laico é garantia essencial para o exercício dos direitos humanos, na medida em que a imposição de uma moral única inviabiliza a existência de uma sociedade aberta, pluralista e democrática. Toda religião merece respeito, mas não se pode legitimar a ideia de um falso direito de pretender homogeneizar a cultura de um Estado constitucionalmente laico.

Ocorre que, no Brasil, os movimentos religiosos formados na sua maioria por uma grande massa evangélica têm ganhado força no contexto político nacional, sobretudo, em decorrência da assunção de líderes religiosos ao poder. O processo de mercantilização também no campo da fé demarca a mudança de paradigmas dos templos religiosos e permitiu a transformação de pastores em grandes empresários. Com poder monetário e midiático suficiente para lograr êxito em campanhas publicitárias, somado à importância incondicional que têm para os seus fiéis, chegaram a cargos públicos e estão conseguindo exercer grande influência no processo legiferante. 
Nesse contexto, relembra-se os já citados Projeto de Decreto Legislativo, o PDC no 325/2011²8, de autoria do Deputado João Campos, pastor da Assembleia de Deus, que foi desarquivado no Congresso Nacional e tem como objetivo sustar os efeitos da decisão do Supremo Tribunal Federal que reconheceu como entidade familiar a união entre pessoas do mesmo sexo, bem como a Ação Direta de Inconstitucionalidade no 4966, promovida pelo Partido Social Cristão, contra a Resolução no 175/2013 do CNJ, que permitiu a conversão da união estável homoafetiva em casamento.

Todavia, essa tentativa de impor a moral, os "bons costumes" e as crenças religiosas acima da gramática dos direitos humanos não tem espaço em Estados democráticos e seculares, como é o caso do Brasil. Dessa forma, faz necessário fortalecer o princípio da laicidade estatal, por meio da Declaração sobre Eliminação de todas as formas de Discriminação com base em Intolerância Religiosa, e reforçar a interpretação progressista no campo religioso, com o objetivo de incluir e respeitar os direitos humanos.

\section{CONSIDERAÇÕES FINAIS}

A ruptura de paradigmas em relação à diversidade sexual perpetrada nos últimos anos na América Continental e na Europa Ocidental fez com essas sociedades se tornassem mais plurais, mais diversificadas, não se traduzindo mais no modelo tradicional radicado na prevalência do homem branco, rico e heterossexual.

Esse processo possibilitou uma onda de reconhecimento dos direitos LGBTI nas esferas global, regional e local. No entanto, houve apenas uma parcial inclusão desse público na sociedade. No Brasil, apenas a união civil entre pessoas do mesmo sexo foi chancelada judicialmente e, por esse motivo, uma série de prerrogativas que integram o direito à diversidade sexual não foram garantidas e ainda carecem de efetividade.

Faz-se necessário, portanto, reforçar o ideal de sociedade justa e igualitária, o princípio da laicidade estatal, bem como enfrentar os efeitos perversos da globalização econômica, conforme se assinalou ao longo deste trabalho. A diferença precisa ser visibilizada para impedir que direitos sejam aniquilados, na medida em que, na atual conjuntura global, não há mais espaço para o discurso hegemônico que pretende reproduzir socialmente a visão da família patriarcal.

Nesse contexto, deve emergir a compreensão de que a ordem jurídica internacional restringe a atuação do sistema jurídico doméstico e limita a sua produção legiferante. Com efeito, após o advento da Resolução de 2014 do Conselho de Direitos Humanos das Nações Unidas, a qual incluiu as diferentes orientações sexuais e a

\footnotetext{
28 O acompanhamento do PDC no 325/2011 encontra-se disponível no site: $<$ http://www.camara.gov.br/proposicoesWeb/fichadetramitacao?idProposicao=511719>. 
livre vivência de gênero como direitos humanos, não há mais como afastar esses temas da agenda política brasileira e tampouco seguir perpetrando violações nessa área, sob quaisquer justificativas, inclusive, fundamentos religiosos ou morais.

Faz-se emergencial avançar no processo de luta por direitos e por justiça das minorias sexuais, clamando por igualdade, dignidade e respeito, com a eliminação do preconceito e da discriminação, no marco de uma sociedade aberta, pluralista, democrática e radicada na prevalência da dignidade humana.

\title{
SEXUAL DIVERSITY AND THE GLOBAL CONTEXT: CHALLENGES FOR THE FULL IMPLEMENTATION OF THE LGBTI HUMAN RIGHTS
}

\author{
Abstract \\ This article aims to study the global challenges that prevent the full implementation of the sexual diversity right in \\ Brazil. To do so, the protection of sexual minority human rights in the international order was verified through the \\ global system of human rights and cases of the European and Inter-American Human Rights' Courts. Internally, \\ the aim was to analyze the effectiveness of the fundamental right to sexual diversity, studying the emblematic cases \\ decided by the Brazilian Courts. In the end, three factors that prevent the realization of that right were listed: \\ 1. The lack of recognition of sexual minority rights as a human right; \\ 2. The economic globalization process, and \\ 3. The emergence of religious fundamentalism. \\ As a result, it is pointed out to a partial inclusion of the population in the society, which reaffirms the importance of \\ the struggle for full realization of these rights, so to each individual lies the guaranty to free express your human \\ sexuality.
}

Keywords: 1. Human Rights 2. Sexual Diversity. 3. Struggle for Dignity. 4. Effectiveness. 5. Global Context.

\section{REFERÊNCIAS BIBLIOGRÁFICAS}

BRASIL. Constituição Federal, de 05 de outubro de 1988. Diário Oficial, Brasília, 1988. Disponível em: <http://www.planalto.gov.br/ccivil_03/constituicao/ConstituicaoCompilado.htm>. Acesso em: 23 nov. 2015. Lei no 11.340, de 07 de agosto de 2006. Diário Oficial, Brasília, 2006. Disponível em: <http://www.planalto.gov.br/ccivil_03/_ato2004-2006/2006/lei/11 1340.htm>. Acesso em: 22 nov. 2015.

Decreto no 592, de 6 de julho de 1992. Promulga o Pacto Internacional de Direitos Civis e Políticos.

Diário Oficial, Brasilia, 1992. Disponível em: <http://www.planalto.gov.br/ccivil_03/decreto/19901994/D0592.htm>. Acesso em: 23 nov. 2015. 
Decreto no 678, de 06 de novembro de 1992. Promulga a Convenção Americana de Direitos Humanos. Diário Oficial, Brasília, 1992. Disponível em: <http://www.planalto.gov.br/ccivil_03/decreto/D0678.htm>. Acesso em: 23 nov. 2015.

Câmara dos Deputados. Projeto de Decreto Legislativo n * 325/2011, de 06 de julho de 2011. Autor:

João Campos - PSDB/GO. Brasília, 2011. Disponível em:
<http://www.camara.gov.br/proposicoesWeb/fichadetramitacao?idProposicao=511719>. Acesso em: 23 nov. 2015.

Supremo Tribunal Federal. Arguição de Descumprimento de Preceito Fundamental no 132-RJ. Requerente: Governador do Estado do Rio de Janeiro. Relator: Min. Carlos Ayres Britto. Brasília, 2011. Disponível em: $<$ http://redir.stf.jus.br/paginadorpub/paginador.jsp?docTP=AC\&docID=628633>. Acesso em: 23 nov. 2015.

Supremo Tribunal Federal. Recurso Extraordinário no 845.779. Recorrente: André dos Santos Fialho. Recorrido: Beiramar Empresa Shopping Center Ltda. Relator: Min. Roberto Barroso. Brasília, 2015. Disponível em: <http://www.stf.jus.br/portal/processo/verProcessoAndamento.asp?incidente $=4657292>$. Acesso em: 23 nov. 2015

Supremo Tribunal Federal. Habeas Corpus 79.285/RJ. Impetrante: Agostinho Campos. Paciente: Silvan Rocha Guedes. Relator: Min. Moreira Alves. Brasília, 1999. Disponível em: <http://redir.stf.jus.br/paginadorpub/paginador.jsp?docTP=AC\&docID=78021 . Acesso em: 23 nov. 2015.

Superior Tribunal de Justiça. Recurso Especial 1.540.814/PR Recorrente: Ministério Público do Estado do Paraná. Recorrido: R. G. da S. Relator: Min. Ricardo Villas Bôas Cueva. Brasília, 2015. Disponível em: $<$ https://ww2.stj.jus.br/processo/revista/documento/mediado/?componente=ATC\&sequencial=50200849\& num_registro $=201102747631 \&$ data $=20150825 \&$ tipo $=51 \&$ formato=PDF $>$. Acesso em: 23 nov. 2015.

Superior Tribunal de Justiça. Recurso Especial 1.183.378/RS. Recorrente: K. R. O. e L. P. Recorrido: Ministério Público do Estado do Rio Grande do Sul. Brasília, 2011. Disponível em: <http://www.direitohomoafetivo.com.br/anexos/juris/1145_8e50218447062b2adb0d0163135bdeb5.pdf>. Acesso em: 23 nov. 2015.

Tribunal Regional Federal da Segunda Região. Apelação Cível nº 0033834-70.1998.4.02.0000. Apelante: União Federal. Apelado: Rubens da Cruz Pinheiro. Relator: Juiz Convocado Marcelo Pereira. Rio de Janeiro, 2009. Disponível em: <http://www10.trf2.jus.br/consultas/?movimento=cache\&q=cache:CW9r7A7N6kJ:trf2nas.trf.net/iteor/TXT/RJ0108810/1/119/285046.rtf \&site=v2_jurisprudencia\&client=v2 _index\&proxystylesheet=v2_index\&lr=lang_pt\&ie=UTF-8\&output=xml_no_dtd\&access=p\&oe=UTF-8>.

Acesso em: 23 nov. 2015.

Tribunal Regional Federal da Segunda Região. Apelação Cível no 2009.51.01.029808-4. Apelante: Carlos Roberto Flores da Silva. Apelado: União Federal. Relator: Des. Federal Reis Friede. Rio de Janeiro, 2012. Disponível

em:<http://www10.trf2.jus.br/consultas/?movimento=cache\&q=cache:dNvXn3G00noJ:trf2nas.trf.net/iteor/T XT/RJ0108710/1/165/432611.rtf \&site=v2_jurisprudencia\&client=v2_index\&proxystylesheet $=\mathrm{v} 2$ _index\&lr =lang_pt\&ie=UTF-8\&output=xml_no_dtd\&access=p\&oe=UTF-8 $>$. Acesso em: 23 nov. 2015.

CONSELHO DA EUROPA, Convenção Europeia de Direitos Humanos, de 04 de novembro de 1950. Roma, 1950. Disponível em: <http://www.echr.coe.int/Documents/Convention_POR.pdf>. Acesso em: 15 jul. 2015. Corte Europeia de Direitos Humanos. HUDOC. Disponível em: $<$ http://hudoc.echr.coe.int/eng\#\{"documentcollectionid2":["GRANDCHAMBER","CHAMBER"]\}>. Acesso em: 23 nov. 2015. 
CONSELHO FEDERAL DE MEDICINA. Resolução no 1.955, de 03 de setembro de 2010. Dispõe sobre a cirurgia de transgenitalismo e revoga a Resolução CFM no 1.652/02. Diário Oficial. Brasília, 2010. Disponível em: <http://www.portalmedico.org.br/resolucoes/CFM/2010/1955_2010.htm>. Acesso em: 22 nov. 2015.

CONSELHO NACIONAL DE JUSTIÇA. Resolução no 175, de 14 de maio de 2013. Dispõe sobre a habilitação, celebração de casamento civil, ou de conversão de união estável em casamento, entre pessoas de mesmo sexo. Diário Oficial, Brasília, 2013. Disponível em: <http://www.cnj.jus.br/images/resol_gp_175_2013.pdf>. Acesso em: 23 nov. 2015.

___ Enunciados 42 e 43, de 15 de maio de 2014. I Jornada de Direito da Saúde. São Paulo, 2014. Disponível em:

$<$ http://www.cnj.jus.br/images/ENUNCIADOS_APROVADOS_NA_JORNADA_DE_DIREITO_DA_S AUDE_\%20PLENRIA_15_5_14_r.pdf $>$. Acesso em: 22 nov. 2015.

DIAS, Maria Berenice. União homoafetiva: o preconceito \& a justiça. 4a ed. São Paulo: Ed. RT, 2009.

FACHIN, Luiz Edson. Comentários ao novo Código Civil: do direito de família, do direito pessoal, das relações de parentesco. Rio de Janeiro: Forense, 2004.

FALK, Richard. Globalização Predatória: uma crítica. Lisboa: Instituto Piaget, 1999.

FLORES, Joaquín Herrera. Direitos Humanos, Interculturalidade e Racionalidade de Resistência, mimeo.

FRASER, Nancy. From Redistribution to Recognition? Dilemmas of Justice in a Postsocialist age in Justice Interruptus. Critical reflections on the "Postsocialist" condition.NY/London, Routledge, 1997.

HONNETH, Axel. Redistribution or Recognition? A political-philosophical exchange. London/NY, verso, 2003.

GIRARDI, Viviane. Famílias Contemporâneas, Filiação e Afeto: a possibilidade jurídica da adoção por homossexuais. Porto Alegre: Livraria do Advogado, 2005.

GORISCH, Patrícia. O Reconhecimento dos Direitos Humanos LGBTI: de Stonewall à ONU. Curitiba: Appris, 2014.

GUTMANN, Amy. Multiculturalism: examining the politics of recognition. Princenton, Princenton University Press, 1994.

HONNETH, Axel. The Struggle for Recognition: The moral grammar of social conflicts. Cambridge/Massachussets, MIT Press, 1996.

INTERNATIONAL LESBIAN AND GAY ASSOCIATION. State-Sponsored Homophobia, A World Survey of Laws: criminalisation, protection and recognition of same-sex love. $10^{\mathrm{a}}$ ed. Disponível em $<$ http://old.ilga.org/Statehomophobia/ILGA_State_Sponsored_Homophobia_2015.pdf $>$. Acesso em: 22 jul. 2015. 
MILHORANCE, Flávia. Mais um ponto final na luta dos homossexuais. O Globo, São Paulo, 16 dez. 2012. Sociedade, Saúde. Disponível em: <http://oglobo.globo.com/sociedade/saude/mais-um-ponto-final-na-lutados-homossexuais-7059597>. Acesso em: 22 nov. 2015.

ORGANIZAÇÃO DAS NAÇÕES UNIDAS. Assembleia Geral. Declaração Universal dos Direitos Humanos, de 10 de dezembro de 1948. Paris, 1948. Disponível em: <http://www.ohchr.org/EN/UDHR/Documents/UDHR_Translations/por.pdf>. Acesso em: 23 nov. 2015.

Assembleia Geral. Pacto Internacional dos Direitos Econômicos, Sociais e Culturais, de 16 de dezembro

de 1966. Nova Iorque, 1966. Disponível em: <

http://www.ohchr.org/EN/ProfessionalInterest/Pages/CESCR.aspx>. Acesso em: 23 nov. 2015.

Alto Comissariado para os Direitos Humanos. Comitê de Direitos Humanos. Recomendação Geral 14,

de 16 de março de 1993. Disponível em:

<http://tbinternet.ohchr.org/_layouts/treatybodyexternal/Download.aspx?symbolno=INT\%2fCERD\%2fGEC \%2f7486\&Lang=en>. Acesso em: 22 nov. 2015.

Alto Comissariado para os Direitos Humanos. Comitê de Direitos Humanos. Recomendação Geral 18, de 10 de novembro de 1989. Disponível em: < http://tbinternet.ohchr.org/_layouts/treatybodyexternal/_Download.aspx?symbolno=INT\%2fCCPR\%2fGEC \%2f6622\&Lang=en>. Acesso em: 22 nov. 2015.

Alto Comissariado para os Direitos Humanos. Comitê dos Direitos Econômicos, Sociais e Culturais. Recomendação Geral 16, de abril/maio de 2005, Genebra, 2005. Disponível em: < http://docstore.ohchr.org/SelfServices/FilesHandler.ashx?enc=4slQ6QSmlBEDzFEovLCuW1AVC1NkPsgUe dPIF1vfPMJpdX7m2Tx5L7detnk4aL8Sk\%2bOCLoaHsUFVMh6SviNU92S8cbmrriTaya9N9pSBR\%2b0tHiI \%2fLewK1gfET938Og3y >. Acesso em: 23 nov. 2015.

Alto Comissariado para os Direitos Humanos. Comitê dos Direitos Econômicos, Sociais e Culturais. Recomendação Geral 20, de 02 de julho de 2009. Genebra, 2009. Disponível em: <http://docstore.ohchr.org/SelfServices/FilesHandler.ashx?enc=4slQ6QSmlBEDzFEovLCuW1a0Szab0oXTd ImnsJZZVQdqeXgncKnylFC\%2blzJjLZGhsosnD23NsgR1Q1NNNgs2QltnHpLzG\%2fBmxPjJUVNxAedgozi xcbEW9WMvnSFEiU\%2fV>. Acesso em: 23 nov. 2015.

Alto Comissariado para os Direitos Humanos. Comitê de Direitos Humanos. Comunicação 488/1992.

Requerente: Nicholas Toonen. Requerido: Austrália. Disponível em: < https://wwwl.umn.edu/humanrts/undocs/html/vws488.htm>. Acesso em: 23 nov. 2015.

ORGANIZAÇÃO DOS ESTADOS AMERICANOS. Assembleia Geral. Resolução n 2653 - XLI-0/11, de 7 de junho de 2011. El Salvador, 2011. Disponível em: <http://www.oas.org/consejo/sp/AG/Documentos/AG05485P05.doc>. Acesso em: 23 nov. 2015.

Corte Interamericana de Direitos Humanos. Caso Atala Riffo y Niñas Vs. Chile. Requerente: Karen Atala $\overline{R i f f o}$ e outros. Requerido: Chile. Costa Rica, 2012. Disponível em: <http://www.corteidh.or.cr/docs/supervisiones/atalayninas_26_11_13_ing.pdf>. Acesso em: 15 jul. 2015.

Conselho Permanente. Comissão de Assuntos Jurídicos e Políticos. Discursos e palestras durante a

Sessão Especial de Reflexão e Análise sobre a natureza de uma futura Convenção Interamericana contra o Racismo e todas formas de Discriminação e Intolerância. Washington, 2005. Disponível em: <http://www.oas.org/dil/esp/cajp.rdi15.orig.doc>. Acesso em: 22 nov. 2015.

Conselho Permanente. Comissão de Assuntos Jurídico e Políticos. Estudio elaborado por la Comisión Interamericana de Derechos Humanos "CIDH" en cumplimiento de la resolución AG/RES. 2653 (XLI-O/11): 
Derechos Humanos, Orientación Sexual e Identidad de Género. Washington, 2012. Disponível em: < http://www.oas.org/dil/esp/CP-CAJP-INF_166-12_esp.pdf>.Acesso em: 23 nov. 2015.

ORGANIZAÇÃO MUNDIAL DA SAÚDE. Código Internacional de Doenças. 10ª rev. Estados Unidos, 2010. Disponível em: <http://apps.who.int/classifications/icd10/browse/2016/en\#/F64.0>. Acesso em: 22 nov. 2015.

PICKETT, Brent. The Stanford Encyclopedia of Philosophy. Fall 2015 Edition, Edward N. Zalta (ed.). Disponível em: <http://plato.stanford.edu/archives/fall2015/entries/homosexuality/>. Acesso em: 15 nov. 2015.

PIOVESAN, Flávia. Temas de Direitos Humanos. 7a ed. São Paulo: Saraiva, 2014.

POLIKOFF, Nancy D. Beyond (straight and gay) marriage: valuing all families under the law. Boston: Beacon Press, 2008.

REISMAN, Judith. Kinsey: Crimes \& Consequences, The Red Queen \& The Grand Scheme. $4^{a}$ ed. Institute for Media Education, 2012.

SANTOS, Boaventura de Sousa. Para Uma Concepção Multicultural dos Direitos Humanos. Contexto Internacional, Rio de Janeiro, vol. 23, no 1, p. 07-34, jan./ jun. 2001.

SILVA, Sandro Gorski. A segmentação do consumo e o Pink Market: uma análise do mercado LGBT. Revista de Direito Empresarial, Belo Horizonte, ano 12, n. 1, p. 179-193, jan./abr. 2015.

MCLUHAN, Marshall. The Gutenberg Galaxy; The Making of Typographic Man. Toronto, University of Toronto Press, 2011.

MINISTÉRIO DA SAÚDE. Portaria no 2.803, de 19 de novembro de 2013. Redefine e amplia o Processo Transexualizador no Sistema Único de Saúde. Diário Oficial da União, Brasília, 2013. Disponível em: <http://bvsms.saude.gov.br/bvs/saudelegis/gm/2013/prt2803_19_11_2013.html>.Acesso em:23 nov. 2015.

STOP TRANS PATHOLOGIZATION. Campanha Internacional Stop Trans Pathologization. 2009. Disponível em: <http://www.stp2012.info/old/pt>. Acesso em: 22 nov. 2015.

TAYLOR, Charles. The politics of recognition in: TAYLOR, Charles et. al., Multiculturalism - Examining the politics of recognition. Princeton, Princeton University Press, 1994.

YOUNG, Iris. Justice and the politics of difference. Princenton, Princenton University Press, 1990.

Trabalho enviado em 13 de setembro de 2015.

Aceito em 02 de dezembro de 2015. 